
NOTICE

This report was prepared as an account of work sponsored by the United States Government. Neither the United States nor the Department of Energy, nor any of their employees, nor any of their contractors, subcontractors, or their employees, makes any warranty, express or implied, or assumes any legal liability or responsibility for the accuracy, completeness or usefulness of any information, apparatus, product or process disclosed, or represents that its use would not infringe privately owned rights.

The views, opinions and conclusions contained in this report are those of the contractor and do not necessarily represent those of the United States Government or the United States Department of Energy.

\author{
PACIFIC NORTHWEST LABORATORY \\ operated by \\ BATTELLE \\ for the \\ UNITED STATES DEPARTMENT OF ENERGY \\ Under Contract EY-76-C-06-1830
}

\author{
Printed in the United States of America \\ Available from \\ National Technical Information Service \\ United States Department of Commerce \\ 5285 Port Royal Road \\ Springfield, Virginia 22151
}

Price: Printed Copy $\$$

*; Microfiche $\$ 3.00$

NTIS

*Pages Selling Price

$\begin{array}{ll}001-025 & \$ 4.00 \\ 026-050 & \$ 4.50 \\ 051-075 & \$ 5.25 \\ 076-100 & \$ 6.00 \\ 101-125 & \$ 6.50 \\ 126-150 & \$ 7.25 \\ 151-175 & \$ 8.00 \\ 176-200 & \$ 9.00 \\ 201-225 & \$ 9.25 \\ 226-250 & \$ 9.50 \\ 251-275 & \$ 10.75 \\ 276-300 & \$ 11.00\end{array}$


PNL-1948

\title{
Radioactivity Associated with Biota and Soils of the 216-A-24 Crib
}

\author{
E. L. Klepper \\ L. E. Rogers \\ J. D. Hedlund \\ R. G. Schreckhise
}

March 1979

This report was sponsored by Rockwell Hanford Operations

A Prime Contractor for the U.S. Department of Energy under Contract EY-76-C-06-1830

Pacific Northwest Laboratory

Richland, Washington 99352 


\section{ACKNOWLEDGMENTS}

This report is published with funds from the Department of Energy (formerly the Energy Research and Development Administration) under support contract to the Rockwell Hanford Operations (formerly Atlantic Richfield Hanford Company, ARHCO).

We thank Keith Price and Harold Maxfield of ARHCO for suggesting and helping to scope the project and for reviewing the manuscript. The field work could not have been done without the excellent cooperation of $N$. K. Pope of $A R H C O$ who provided radiation monitoring services throughout the study. Larry Hutton of ARHCO did the field survey and provided the readings in Appendix II. Art Case of Battelle did the gamma energy analyses; ${ }^{90} \mathrm{Sr}$ analyses were done by U.S. Testing. Backhoe excavations were done by Curtis Hagen of ARHCO. Several of the research aspects of this study were supported either directly or indirectly through on-going projects funded by $V$. A. Uresk for ARHCO.

Field observations and collections of biological materials were done with the help of M. J. Harris, M. A. Combs, L. E. Renda11, D. T. McCullugh, and K. A. Gano. Annual growth ring analyses in Appendix I were provided by M. J. Harris. Scotty Getchell took the photographs. 


\section{EXECUTIVE SUMMARY}

The 216-A-24 Crib was built in 1957 and was used from 1958 to 1966 to receive condensate from the 241-A and 241-AX Tank Farms. As of December 1974, the crib still retained an estimated $385 \mathrm{Ci}$ of ${ }^{137} \mathrm{Cs}$ and $27 \mathrm{Ci}$ of ${ }^{0} \mathrm{Sr}$. In 1975, rabbitbrush plants (Chrysothamnus nauseosus) growing on the crib were found to contain radioactive materials.

Highest levels of activity and densest stands of rabbitbrush plants were in the center of the second section of the crib where a Geiger-Muller count rate meter showed surface exposure rates of certain plants to be as high as 125 times background. Of the 519 shrubs on the second section, 364 were at background, 62 were up to 10 times background, and 93 were over 10 times background. Contaminated shrubs were restricted to the center of the crib. All shrubs more than 6 meters away from the centerline were at background levels. The shrubs were, on the average, 9.4 years old (range 6-12 years).

The radionuclide involved was primarily ${ }^{137} \mathrm{Cs}$. Other fission products were observed, but levels were at or near detection limits. Soil excavations showed that rabbitbrush plants were sufficiently deep-rooted to reach the gravel drainfield which is at the 8 foot depth in the shallow end of this crib section. The shrubs appeared to absorb ${ }^{137} \mathrm{Cs}$ and trace amounts of other fission products from within or below the gravel layers. The gravel appeared to retain significant amounts of ${ }^{13^{7}} \mathrm{Cs}$. Soil above the gravel layers was not contaminated al though there were detectable levels of ${ }^{13}{ }^{7} \mathrm{Cs}$ in the rabbitbrush roots which grew through that soil. Cesium-137 was detectable in the upper $\mathrm{cm}$ of soil and in the 1itter, especially beneath canopies of plants with high levels of ${ }^{137} \mathrm{Cs}$ in their leaves. However, at the $15 \mathrm{~cm}$ depth, ${ }^{13.7} \mathrm{Cs}$ was not detectable in the soil. Consequently, deep excavation will not be required for decontamination.

Some animal samples collected on the crib contained ${ }^{137} \mathrm{Cs}$. Those insect species associated with a rabbitbrush shrub containing ${ }^{137} \mathrm{Cs}$ and its litter showed higher levels of ${ }^{137} \mathrm{Cs}$ than other wider-ranging species caught in pitfall traps and by hand. Two out of seven pocket mice contained detectable amounts of ${ }^{3{ }^{7}} \mathrm{Cs}$ with $70 \%$ of the total body burden in the muscle and skeleton.

Recommendations for restoration of the crib surface, if appropriate, include eradication of rabbitbrush plants, removal of the surface centimeter of soil on the central 12 meters of the crib, removal of the cobble layer from the surface, installation of a one-foot layer of clean soil and revegetation of the surface with cheatgrass. An effort should be made to keep road traffic off the new surface so that plants can maintain continuous cover. 


\section{TABLE OF CONTENTS}

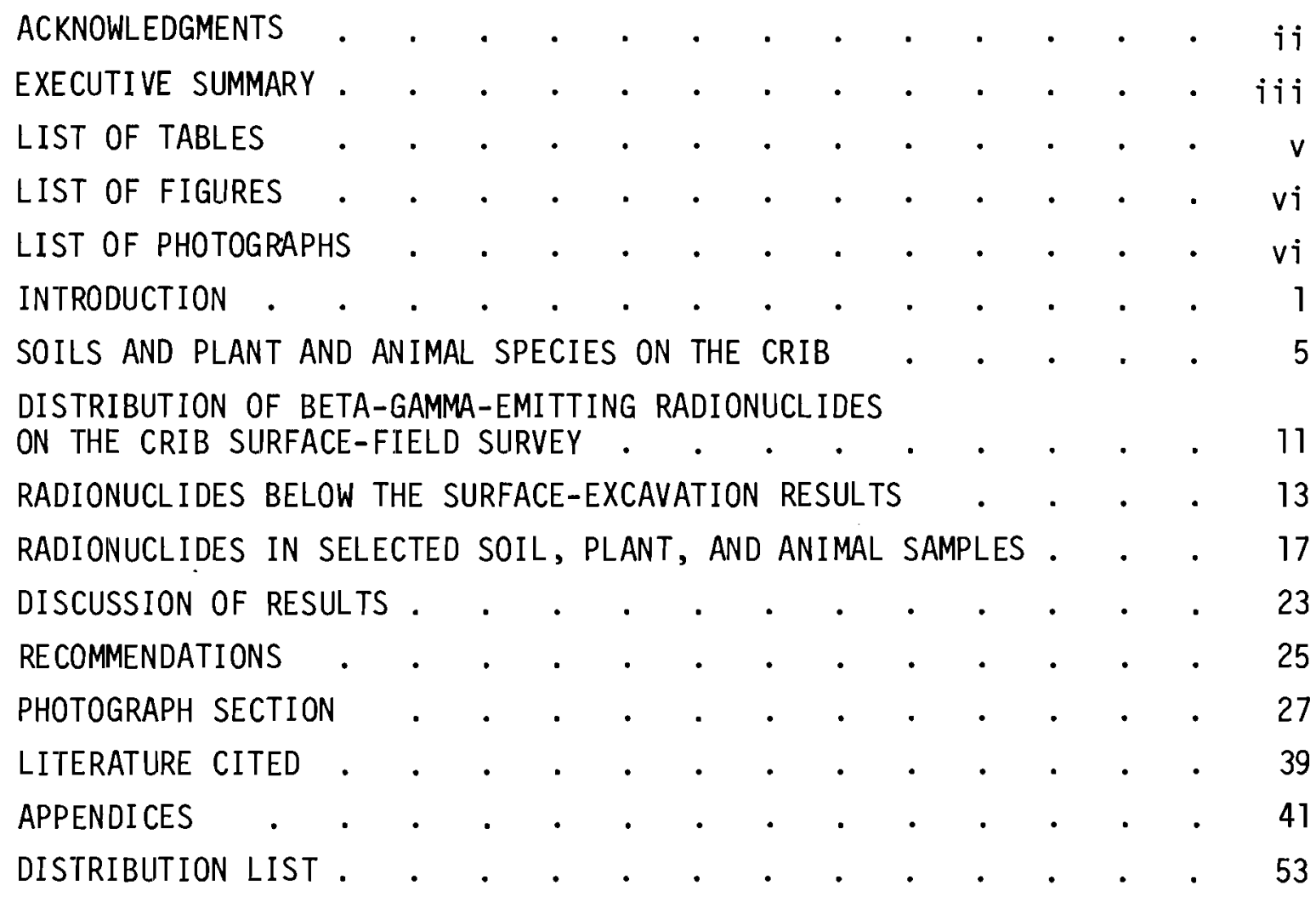




\section{LIST OF TABLES}

1.1 Radioactivity Remaining in the 216-A-24 Crib as of December 31, 1974 . . . . .

2.1 Comparison of Shrub Density (number per $500 \mathrm{~m}^{2}$ ) on the Second Section of the 216-A-24 Crib with Values for the B-C Crib Control Area and the REDOX Area

2.2 Harvester Ant (Pogonomyrmex owyheei) Colony Density (numbers per crib section) within Crib 216-A-24 . . . . 8

2.3 Taxonomic Composition, Density, and Biomass of Invertebrates Associated with Chrysothamnus nauseosus $\cdot \cdot \cdot \cdot \cdot \cdot \cdot \cdot \cdot$

2.4 Harvester Ant (Pogonomyrmex owyheei) Nest Characteristics. . .. . . . . . . . . 10

4.1 Radiocesium in Soils and Rabbitbrush Roots at Various Depths in the 216-A-24 Crib... . . . . . . . 14

4.2 Cesium-137 in Gravel and Soil Collected from the
Bottom of Section I of the 216-A-24 Crib

4.3 Cesium-137 in the Wood and Bark of the Taproot and Lateral Roots of a Rabbitbrush Root System Collected from Excavation in Section II of the 216-A-24 Crib

4.4 Cesium-137 in the Wood and Bark of the Taproot and Lateral Roots of a Rabbitbrush Root System Collected from Excavation in Section II of the 216-A-24 Crib. . . 15

5.1 Radiocesium in Parts of a Contaminated Rabbitbrush Plant from the 216-A-24 Crib... . . . . . 18

5.2 Cesium-137 in Plant And Soil Samples . . . . . . 19

5.3 Concentrations of ${ }^{137} \mathrm{Cs}$ for Invertebrates Collected
on the $216-\mathrm{A}-24 \mathrm{Crib}$. . . . . . . . . . . 21

5.4 Cesium-137 in Pocket Mice Collected on the 216-A-24 . . . 22
Crib. . . . . . . . . . 22

5.5 Radiocesium Levels in Dissected Components of Two Contaminated Pocket Mice Captured on the 216-A-24 Crib 


\section{LIST OF FIGURES}

1.1 Structural Details of the 216-A-24 Crib . . . . . . 2

2.1 Diagram Showing Section II of the Crib and the Location of the Mapped Area . . . . . • . . . . 6

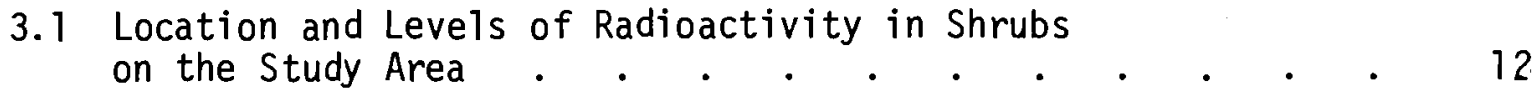

\section{LIST OF PHOTOGRAPHS}

1 A View of Section II of the 216-A-24 Crib . . . . . . . 29

2 A View of the Mapped Area in the Central Section of the Crib . . . . . . . . . . . . . 30

3 A View from the Northwest Corner of the Mapped Area . . . 31

4 A View down the Central Transect of the Mapped Area
Which Ends at the Lower Monitoring Well . . . . . . . 32

5 An Example of the Close Juxtaposition of Radioactive

6 An Example of the Apparent Randomness of the Occurrence
of Radioactivity in Shrubs . . . . . . . . . . 34

7 A Harvester Ant Nest . . . . . . . . . . . . . . • 35

8 The Woody Roots of a Rabbitbrush Plant Growing South of the
Second Section of the $216-\mathrm{A}-24$ Crib . . . . . . . 36

9 Gravel from an Excavation of the Lower End of
Section II of the Crib . . . . . . . . . . . 37 


\section{RADIOACTIVITY ASSOCIATED WITH BIOTA AND SOILS OF THE 216-A-24 CRIB}

\section{INTRODUCTION}

The 216-A-24 Crib is located east of the 200 East area outside the exclusion fence. It is approximately $0.9 \mathrm{miles}$ from the main road connecting the Wye Barricade and the 200 East area main gate. The approximate coordinates are N 42206, W 46854 to N 42494, W 45328.

The crib was constructed in 1ate 1957. Between May, 1958, and January, 1966, it received condensates from the boiling waste storage tanks in the 241-A and 241-AX Tank Farms (Lundgren, 1970). Table 1.1 shows the radioactivity delivered to the crib and that remaining after decay as of December 1, 1974. Cesium-137 is the predominant radionuclide being 14 times as concentrated as ${ }^{90} \mathrm{Sr}$ on a curie basis. Other nuclides, such as ${ }^{106} \mathrm{Ru}$ and ${ }^{60} \mathrm{Co}$, are present in small amounts. These radionuclides are presumably distributed throughout the length of the crib.

TABLE 1.1. Radioactivity Remaining in the 216-A-24 Crib as of December 31, 1974. Data are from Anderson, 1975.

\begin{tabular}{lc} 
& $\begin{array}{c}\text { Remaining } \\
\text { Dec.31, 1974 } \\
\text { (curies) }\end{array}$ \\
\cline { 2 - 2 } Beta & 795 \\
${ }^{90} \mathrm{Sr}$ & 27.0 \\
${ }^{106} \mathrm{Ru}$ & 0.069 \\
${ }^{137} \mathrm{Cs}$ & 385 \\
${ }^{60} \mathrm{Co}$ & 0.093
\end{tabular}

The structure of the crib is shown in Figure 1.1. It consists of four sections, each 350 feet long. Condensates from the tank farm were delivered to the head of the crib and drained into a gravel drainfield through perforations in a 15-inch-diameter pipe. Depth of this perforated pipe from finished grade varies from about 15 feet at the upper end of each crib section to about 8 feet at the lower end of each section. The pipe is covered with gravel over which a polyethylene sheet was installed to prevent sand from the overlying backfill material from sifting into the gravel bed. This sheet, while still intact, would also discourage penetration of plant roots into the drainfield. 
CRIB 216-A-24

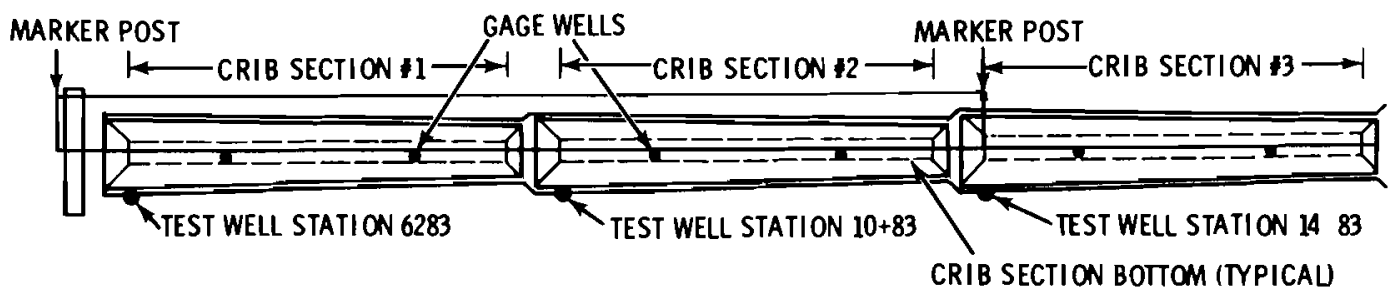

TYPICAL LONGITUDINAL SECTION

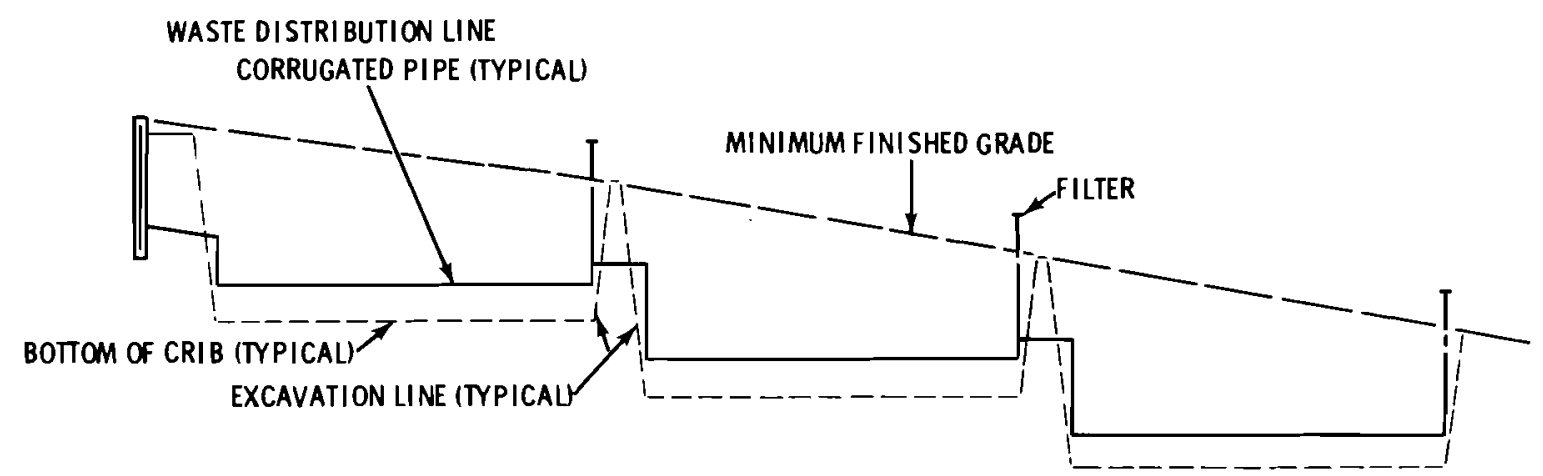

PROFILE STATION $6+08$ TO 22+83 (END)

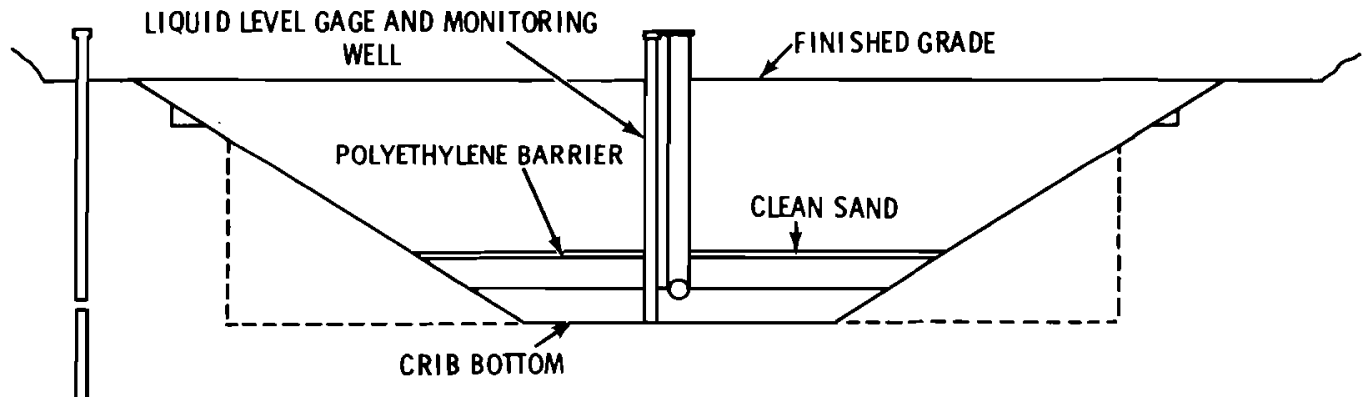

TYPICAL CROSS SECTION

FIGURE 1.1. Structural Details of the 216-A-24 Crib 
In the spring of 1975, plants growing on this crib were found to emit sufficient radioactivity to register significantly above background in routine radiation monitoring. Presumably, roots of these plants were absorbing radioactive materials from deep in the soil profile or directly from the gravel bed. However, shrubs adjacent to one another were found to contain levels of radioactivity different by orders of magnitude, indicating that rooting depth or extent, species specific uptake characteristics, or bush size or vigor might be implicated.

Work reported in this document was done to investigate the surface soils, plants, and animals on the crib with the following objectives in mind.

- Document location, approximate age, and level of radioactivity in shrubs on the part of the 216-A-24 Crib shown as Section II in Figure 1.1 and determine the major nuclides involved.

- Determine from the observed distribution pattern of contaminated plants the probable source of contamination and the reason for the apparently erratic spatial distribution of contaminated shrubs on the crib, including root system excavation studies if permissible.

- Document any spread of radioactivity from contaminated foliage of the bushes to other plant and animal species on the crib.

- Suggest methods which might be used to restore the surface to stable, non-radioactive condition and to prevent future occurrences of similar problems. 


\section{SOILS AND PLANT AND ANIMAL SPECIES ON THE CRIB}

The 216-A-24 Crib is covered with backfill material which consists mostly of the sandy soils native to the area. However, cobble layers occur about 2-3 meters below the surface in the native profile and some rocks from these cobble layers are mixed with soil in the backfill material. When the crib was constructed, large cobbles were spread to stabilize the surface against wind erosion (K. R. Price, personal communication).

Plant cover is dominated by two species: rabbitbrush (Chrysothamnus nauseosus), an perennial shrub, and cheatgrass (Bromus tectorum), an annual grass. There are scattered sagebrush (Artemisia tridentata) among the rabbitbrush. Occasional herbs other than cheatgrass were found in a survey in early May. These included substantial amounts of Holosteum umbellatum, Descurainia pinnata, and Festuca octoflora; moderate amounts of Cryptantha circumscissa, Sisymbrium altissimum, Salsola kali, and Ambrosia acanthicarpa; and smal1 amounts of Lomatium macrocarpus, Microsteris gracilis, Poa secunda, and a species of Denothera.

Cheatgrass stands are sparse in areas where cobbles cover the soil surface and are more luxuriant beneath shrubs and in areas where the surface material is soil. Cheatgrass shoots beneath shrub canopies are lighter green, larger and more succulent than those between bushes. This could be important if the more succulent plants are more palatable to animals because cheatgrass growing beneath contaminated shrubs was found to contain radiocesium. (See Section 5 , Table 5.2.)

The second section of the crib was chosen as an intensive study area (Figure 2.1, Photograph 1). The upper (western) end of the section is sparsely populated with bushes, but a dense stand occurs in the lower end; and, as will be discussed in the next chapter, most of the shrubs containing radionuclides occur in the lower half of the section. Therefore, the crib section was divided into three parts: an upper section extending $53 \mathrm{~m}$ from the large, green vent; a middle section $44 \mathrm{~m}$ in length, the center of which was mapped in detail (Photographs 2 and 3); and a lower section $26 \mathrm{~m}$ long extending from the lower monitoring well to the lower green vent. The crib radiation zone is $37 \mathrm{~m}$ wide. Bush densities (numbers per $500 \mathrm{~m}^{2}$ ) on these three sections are given in Table 2.1. Compared to two other areas nearby, the 216-A-24 Crib has more rabbi tbrush and less sagebrush, but a total density of bushes per unit area comparable to an area near the REDOX plant.

A transect was laid down the center of the crib in the area marked in Figure 2.1 as "mapped area" (Photograph 4). A11 shrubs overlapping this transect were sampled to determine approximate age from growth rings in transverse stem sections. Stems were cut near the ground surface for 


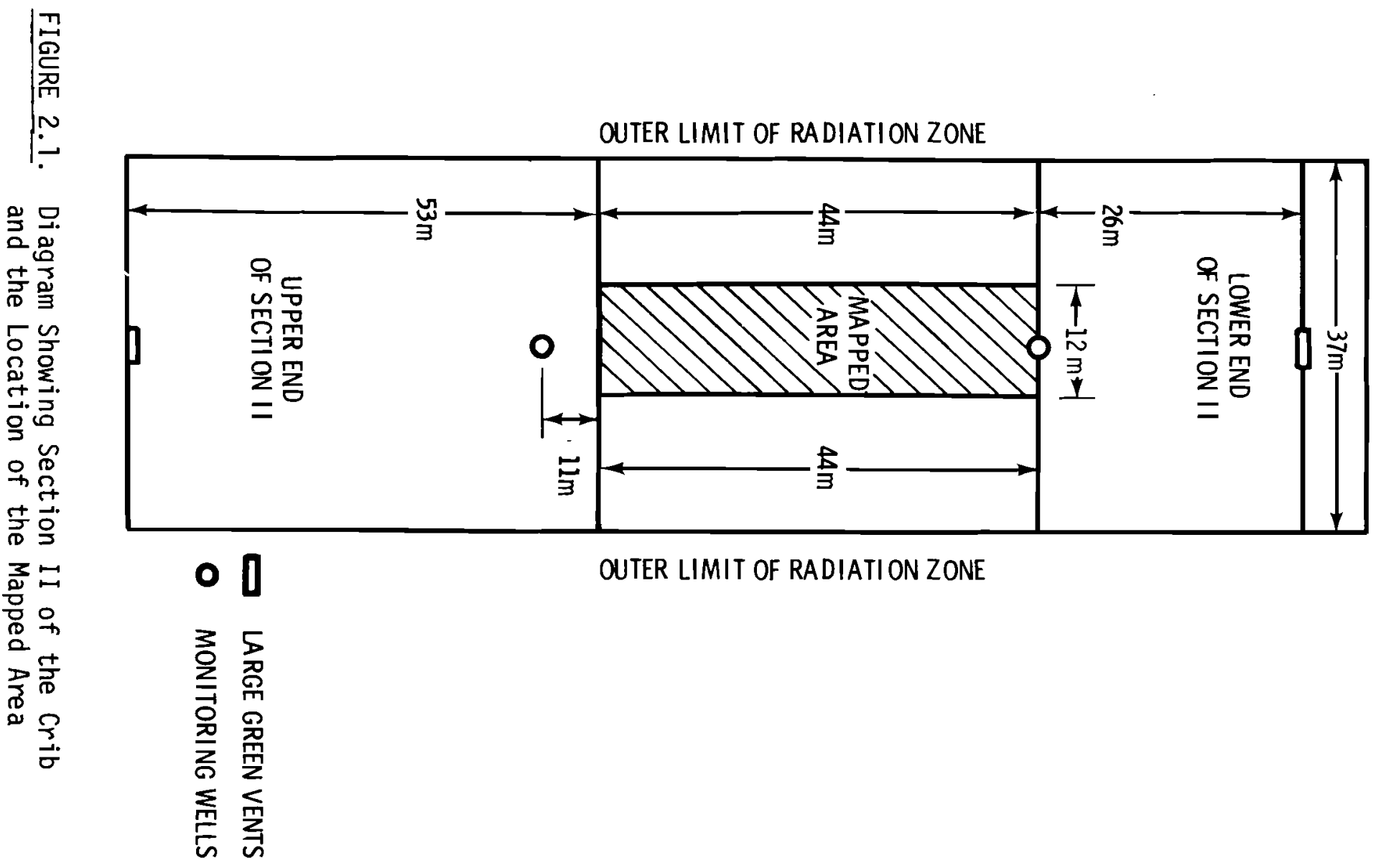


TABLE 2.1. Comparison of Shrub Density (number per $500 \mathrm{~m}^{2}$ ) on the Second Section of the 216-A-24 Crib with Values for the B-C Crib Control Area and the REDOX Area (Comparison Data from $\mathrm{Cl}$ ine, Uresk, and Rickard, 1975)

\begin{tabular}{|c|c|c|c|c|c|c|}
\hline \multirow[b]{2}{*}{ Plant } & \multicolumn{6}{|c|}{$276-A-24$} \\
\hline & Upper & Middle & Lower & Total & $\mathrm{B}-\mathrm{C}$ & REDOX \\
\hline Sagebrush & 2 & 0.3 & 2.1 & 1 & 186 & 42 \\
\hline Rabbitbrush & 16.6 & 95 & 68 & 56 & 2 & 13 \\
\hline Total & 18.6 & 95.3 & 70.1 & 57 & 188 & 55 \\
\hline
\end{tabular}

examination. An assumption was made that the first ring visible in the center of the stem section was from the end of the third year since germination. A further assumption was made that one growth ring indicates one year's growth. This assumption was probably valid since rabbitbrush loses its leaves each year, thus giving a definitive end to the growth period. Furthermore, the climatic pattern (wet winter, dry summer) should accentuate the annual growth ring pattern. Data given in Appendix I show that plants in the center of the crib are 6 to 12 years old with an average age of 9.4 years. They range in height from $40 \mathrm{~cm}$ to $88 \mathrm{~cm}$ and average $64 \mathrm{~cm}$.

Vertebrate animals which would be expected to live on or near the crib or to pass over the crib include snakes, lizards such as the side-blotched lizard (Uta stansburiana), numerous bird species, occasional mule deer (Odocoileus hemionus), black-tailed hares (Lepus californicus), and a number of small mammals, especially the Great Bas in pocket mouse (Perognathus parvus), deer mouse (Peromyscus maniculatus), and grasshopper mouse (onychomys leucogas ter).

On May 1 and 2, twenty-five small mammal traps were set on the second section of the A-24 Crib. On May 1, these yielded four Great Basin pocket mice (2 males, 2 females) and on May 2, three of the same species (1 male, 2 females). Four large mammal traps set on these two nights were unsuccessful. These trapping results indicate that populations of mammals on the crib were relatively sparse.

Invertebrates on the crib surface in early May included a number of species of beetles, leafhoppers, bugs, flies, thrips, lepidopterans, mites, hymenopterans, and ants. The most noticeable populations to the casual observer were harvester ants, which had a total of 104 nests on the crib surface (Table 2.2; Photograph 7), and those insects associated with shrub 
TABLE 2.2. Harvester Ant (Pogonomyrmex owyheei) Colony Density (numbers per crib section) within Crib 216-A-24

\begin{tabular}{cccc} 
Section & Live & Dead & $\frac{\text { Total }}{23}$ \\
\hline 1 & 20 & 3 & 31 \\
2 & 25 & 6 & 26 \\
3 & 22 & 4 & $\frac{24}{104}$ \\
4 & $\frac{23}{90}$ & $\frac{1}{14}$ &
\end{tabular}

canopies (Table 2.3). Twenty pitfall traps, placed on Section II of the crib on May 1 and left in place for 15 days, yielded 15 Tenebrionidae (Eleodes hispilabris) and 10 Curculionidae (Ophryastes sp.), both common ground-dwelling beetles on the 200 Area plateau.

Quantitative information on a single nest of the harvester ant (Pogonomyrmex owyheei) was obtained on May 13 for a nest adjacent to the crib. The numbers of ants, chambers in the nest, and estimates of the volume of soil excavated at several depths are given in Table 2.4. This particular nest extended to a depth of nearly 8 feet (7' $\left.8^{\prime \prime}\right)$. Calculations in Table 2.4 show that over 40 cubic inches of soil were probably moved to the soil surface by this colony and about 20 percent of this soil was brought up from depths greater than 6 feet. Assuming that the excavated nest was "typical" or "average" for the 104 nests on the 216-A-24 Crib, as much as $2.5 \mathrm{ft}^{3}$ of subsurface soils could have been brought to the surface by this species of insect.

In summary, plant and animal populations on the 216-A-24 Crib are typical for disturbed sites on the 200 Area plateau. The soil is sandy and has been covered with cobbles to reduce wind erosion. Stoniness of the soil surface probably has reduced the effectiveness of cover of cheatgrass (see Photograph 2,3, and 4), restricted the abundance of ground-dwelling small mammal species, and encouraged deep penetration and conservation of the sparse annual precipitation in the area. This deep moisture may have contributed to the success of deep-rooted rabbitbrush shrubs on the crib. 
TABLE 2.3. Taxonomic Composition, Density, and Biomass of Invertebrates assocjated with Chrysothamnus nauseosus $(a)$

\begin{tabular}{|c|c|c|}
\hline Taxa & $\begin{array}{l}\text { Density } \\
\text { (Number) }\end{array}$ & $\begin{array}{c}\text { Biomass } \\
\text { (mg) }\end{array}$ \\
\hline \multicolumn{3}{|l|}{ Coleoptera (beetles) } \\
\hline Curculionidae & 7 & 86.98 \\
\hline \multicolumn{3}{|c|}{ Homoptera (leafhoppers, aphids) } \\
\hline Cicadellidae & 10 & 11.98 \\
\hline Aphididae & 2 & 0.39 \\
\hline Psy11idae & 12 & 4.65 \\
\hline \multicolumn{3}{|l|}{ Hemiptera (true bugs) } \\
\hline Reduvi idae & 1 & 3.87 \\
\hline \multicolumn{3}{|l|}{ Diptera (flies) } \\
\hline Sciaridae & 3 & 1.11 \\
\hline Chironomidae & 1 & 0.04 \\
\hline Thys anoptera (thrips) & 5 & 3.58 \\
\hline \multicolumn{3}{|c|}{ Lepidoptera (moths, butterflies) } \\
\hline Noctuidae (larvae) & 8 & 5.48 \\
\hline \multicolumn{3}{|l|}{ Acarina (mites) } \\
\hline Caligonellidae & 3 & 0.01 \\
\hline Unrecognized Prostigmata & 2 & 0.02 \\
\hline Tetranychidae & 1134 & 9.34 \\
\hline \multicolumn{3}{|c|}{ Hymenoptera (wasps, ants, bees) } \\
\hline Cha1 cidoidea & 1 & 0.03 \\
\hline TOTAL & 1199 & 127.48 \\
\hline
\end{tabular}

a. Values were obtained from a single plant (bush 438) and the litter beneath it, collected on May 1, 1975, and subjected to Berlese extraction. 
TABLE 2.4. Harvester Ant (Pogonomyrmex owyheei) Nest Characteristics

\begin{tabular}{|c|c|c|c|c|}
\hline \multirow[b]{2}{*}{ Depth } & \multirow{2}{*}{$\begin{array}{c}\text { Ant } \\
\text { Numbers }\end{array}$} & \multirow{2}{*}{ Chamber } & \multicolumn{2}{|c|}{ Soil Volume Excavated (b) } \\
\hline & & & Per Nest $\left(\mathrm{in}^{3}\right)$ & Entire $\operatorname{crib}(\mathrm{c})\left(\mathrm{in}^{3}\right)$ \\
\hline Mound & 814 & -1 & -- & -- \\
\hline Top $1 \mathrm{ft}$ & 350 & --1 & -- & -- \\
\hline $1-2 \mathrm{ft}$ & 293 & 26 & 11.1 & 1154 \\
\hline $2-3 \mathrm{ft}$ & 217 & 13 & 9.2 & 957 \\
\hline $3-4 \mathrm{ft}$ & 441 & 10 & 7.5 & 780 \\
\hline $4-6 \mathrm{ft}$ & 225 & 10 & 5.4 & 562 \\
\hline $6-8 \mathrm{ft}$ & 1835 & 9 & 9.1 & 946 \\
\hline TOTAL & 4.175 & 68 & 42.3 & 4399 \\
\hline
\end{tabular}

a. The mound and upper foot of the nest was comprised of numerous interconnecting chambers and were not counted.

b. Volume of soil excavated was calculated by summation of volume calculations for chambers and tunnels. Nest excavation conducted on May 15, 1975 near 216-A-24 Crib.

c. Soil volume excavated for the entire crib area was calculated by multiplying soil volume excavated per nest times 104 nests in the study area. 


\section{DISTRIBUTION OF BETA-GAMMA-EMITTING RADIONUCI.IDES ON THE CRIB SURFACE- FIELD STUDY}

A Geiger-Müller survey instrument was used to monitor the area in late April 1975. Measurable amounts of radioactive materials appeared to be restricted to rabbitbrush plants and, in some cases, to the litter beneath them. Surface soils, insects, mice, rabbit fecal pellets, ant hills, cheatgrass, and sagebrush plants were found to be free of contamination readily measurable with a field instrument.

A detailed survey of shrubs on the second section of the crib was conducted by numbering al1 shrubs beginning at the western (upper) end of the crib and surveying each shrub separately. Since leaves, twigs, and branch tips had the highest levels of contamination, the measurements were taken by pressing the probe against 10-20 young twigs and leaves on each plant. Results of this field survey are given in Appendix II.

The upper section of Section II (see Figure 2.1) contained 73 shrubs (65 rabbitbrush and 8 sagebrush), none of which had radioactivity above background measurable with field survey instruments. The central section, including the mapped area and the land on either side, had 311 shrubs ( 310 rabbitbrush and 1 sagebrush). Of these, 198 were at background 1 eve 1 $(<200 \mathrm{cpm}), 47 \mathrm{up}$ to 10 times background $(>200 \mathrm{cpm},<2000 \mathrm{cpm})$, and 66 were $2000 \mathrm{cpm}$ or over (maximum 25,000 cpm). The lower section is $26 \mathrm{~m}$ long and contained 135 shrubs ( 131 rabbitbrush and 4 sagebrush). Of these, 93 were at background levels, 15 up to 10 times background, and 27 were over $2000 \mathrm{cpm}$ (maximum 10,000 cpm). None of sagebrush plants contained contamination detectable in the field survey. The most contaminated shrubs on the section were numbers 139 and 221 which were about 125 times background $(25,000 \mathrm{cpm})$. On the entire section 15 bushes contained $10,000 \mathrm{cpm}$ or over. Of these, 12 bushes are included in the mapped area shown in Figure 3.1a. Circles represent individual bushes with the size of the circle varying with canopy size. Numbers in the circles in Figure 3.1 a refer to the number of the bush. Figure 3.1b shows the same map with the number in the center of the circle being the level of radioactivity in the shrub (see Appendix II) in thousands of counts per minute. Plants having no more than background levels are indicated as blank circles or are shown with a "B". Generally, plants with high levels were surrounded by plants with intermediate levels, but there were instances where adjacent shrubs differed by orders of magnitude (Photographs 5 and 6 ). 

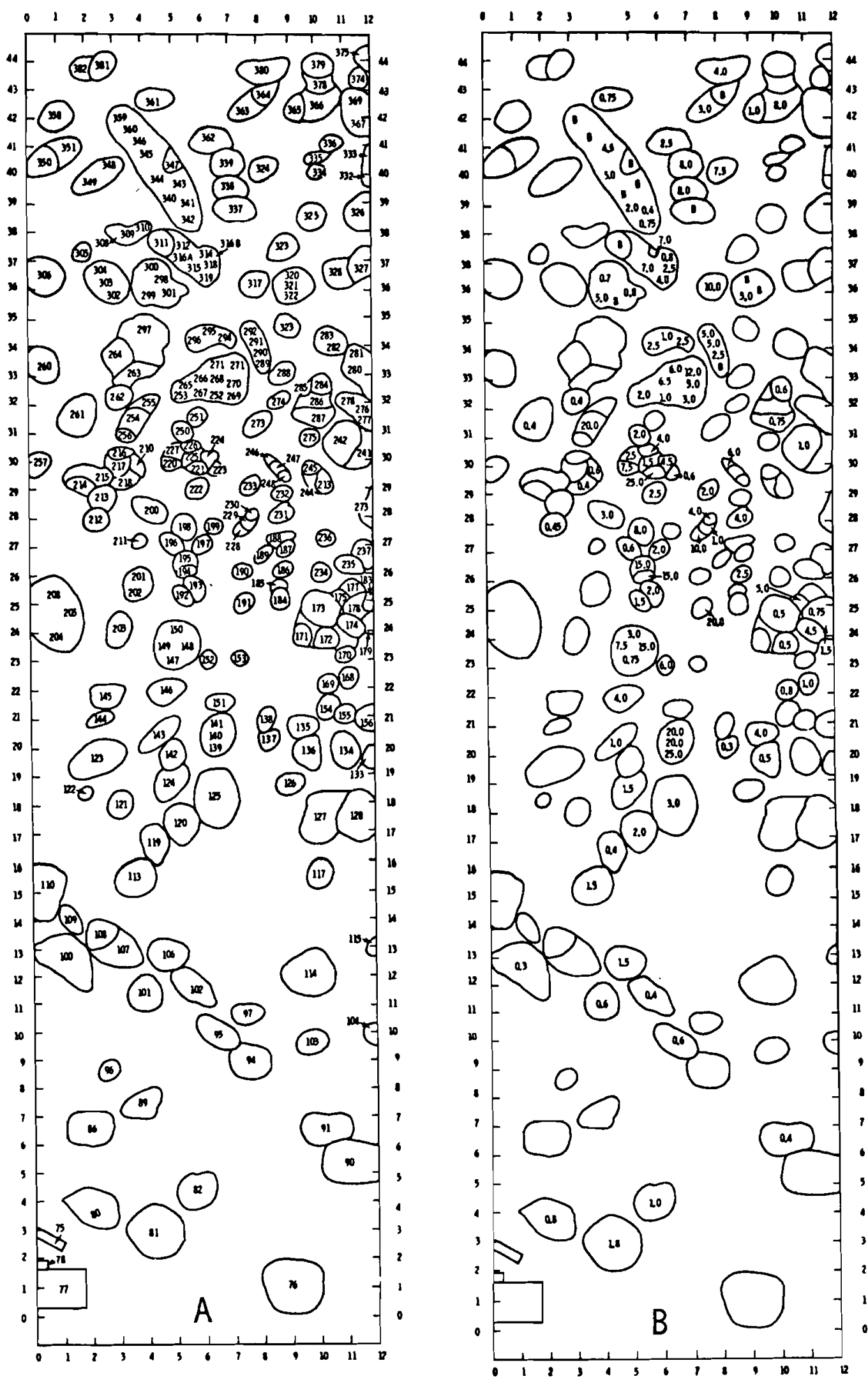

FIGURE 3.1. Location and Levels of Radioactivity in Shrubs on the Study Area. The map on the left shows the location, canopy size, and number assigned to the bushes. The map on the right shows the radioactivity associated with the canopy of each shrub in the thousands of counts per minute. Shrubs at background levels (<200 cpm) are shown as blank except in a few cases where they are designated with a "B". Scale numbers are distances in meters. 


\section{RADIONUCLIDES BELOW THE SURFACE - EXCAVATION RESULTS}

Three backhoe excavations were made into the crib. These will be referred to as $A, B$, and $C$. Excavations $A$ and $B$ were in the lower end of Sections $I$ and II, respectively, about 10 feet west of the green risers which mark ends of crib sections. Both $A$ and $B$ extended down to the grave 1 layer. They were dug to determine whether soils above the gravel layer contained radioactive materials and to observe the condition of the polyethylene sheet (see Figure 1.1) after 17 years of burial in the crib. Excavation $C$ was made about 18 feet west of the green $r$ iser at the lower end of Section II in order to obtain two rabbitbrush root systems for radiochemical analysis.

None of three excavations showed that soils contained amounts of radioactivity detectable with a field instrument. Rabbitbrush roots did occasionally show some activity. Table 4.1 shows the ${ }^{137} \mathrm{Cs}$ levels in samples of soils and roots collected at various depths from excavations $B$ and $\mathrm{C}$.

Although soils above the gravel layers contained no detectable contamination, the gravel layers themselves did have considerable amounts. In both Section I and Section II, gravels from above the drainpipe (see Figure 1.1) registered about $7500 \mathrm{cpm}$ on the field monitoring instrument. Gravel in Section I was damp and was covered with sandy soil; that in Section II appeared dry, but contained obvious rabbitbrush roots. Remnants of a polyethylene sheet were found mixed with the soil in Section I ; there was no evidence of any polyethylene sheet in Section II. Disintegration of the polyethylene sheet in Section I was probably brought about from the gamma radiation from materials in the gravel below the sheet, but other weathering and aging agents are not necessarily ruled out.

A sample of the soil-gravel mixture was removed from Section I and analyzed for ${ }^{137} \mathrm{Cs}$. Results are presented in Table 4.2. Pieces of gravel which had been washed and wiped contained about 10 times the ${ }^{137} \mathrm{Cs}$ on a dry weight basis as did soil from the same sample. This was somewhat unexpected and implies that cesium migrated into the matrix of the grave 1. However, it is possible that the activity could have been removed if the surface of the gravel had been polished or acid washed. A sample of this soil was submitted for gamma energy analysis and ${ }^{90} \mathrm{Sr}$ analys is to U.S. Testing. The gamma scan showed $5.21 \mathrm{nCi} 137 \mathrm{Cs} / \mathrm{gDW}$ which agrees favorably with the value of $3.0 \mathrm{nCi} / \mathrm{gDW}$ reported in Table 4-2 and obtained on a parallel sample by counting on a single channel analyzer. The scan also showed a trace of $134 \mathrm{Cs}$ and $40 \mathrm{~K}$ but no significant ${ }^{60} \mathrm{Co}$. The soil also had $0.0259 \mathrm{nCi} 90 \mathrm{Sr} / \mathrm{gDW}$.

Root systems of two rabbitbrush plants were excavated. One of these (Table 4.3) had $320 \mathrm{nCi}{ }^{137} \mathrm{Cs} / \mathrm{gDW}$ of leaves and the second (Table 4.4) had $2.3 \mathrm{nCi}{ }^{13} \mathrm{Cs} / \mathrm{gDW}$ leaves. Table 4.3 shows that there is an increase in radiocesium concentration in both wood and bark for the taproots and lateral 
TABLE 4.1. Radiocesium in Soils and Rabbitbrush Roots at Various Depths in the 216-A-24 Crib. Soil values are an average from two samples collected about one meter apart from the face of the excavation. Roots, collected from along the face, were pooled into a single sample for each depth.

\begin{tabular}{|c|c|c|}
\hline \multirow{2}{*}{$\begin{array}{l}\text { Depth } \\
\text { (cm) }\end{array}$} & \multicolumn{2}{|c|}{${ }^{137} \mathrm{Cs}$ (nCi/gDW) } \\
\hline & Soil & Roots \\
\hline \multicolumn{3}{|c|}{ - Excavation $B$} \\
\hline 50 & $\mathrm{BDL} *$ & 21 \\
\hline 100 & BDL & 12 \\
\hline 150 & BDL & 160 \\
\hline 200 & BDL & 57 \\
\hline \multicolumn{3}{|c|}{ Excavation C. } \\
\hline 50 & BDL & 4.1 \\
\hline 100 & $\mathrm{BDL}$ & 0.71 \\
\hline 150 & BDL & 9.8 \\
\hline
\end{tabular}

${ }_{\mathrm{BDL}}=$ Below Detection Limits, $\sim 0.1 \mathrm{nCi} / \mathrm{sample}$.

TABLE 4.2. Cesium-137 in Gravel and Soil Collected from the Bottom of Section I of the 216-A-24 Crib. Gravel pieces were rinsed with distilled water and wiped to remove particles of sand and silt adhering to the surface.

\begin{tabular}{|c|c|}
\hline \multicolumn{2}{|c|}{${ }^{137} \mathrm{Cs}$ (nCi/gDW) } \\
\hline Washed Gravel & Soil \\
\hline \multicolumn{2}{|l|}{32.9} \\
\hline 1.56 & 5.89 \\
\hline 45.2 & 0.136 \\
\hline \multicolumn{2}{|l|}{13.7} \\
\hline \multicolumn{2}{|l|}{83.5} \\
\hline$\left(A_{1}\right.$ & 3.0 \\
\hline
\end{tabular}


roots with depth. This trend is also apparent in data for the taproot in Table 4.4, but not for lateral roots. Nevertheless, the data show that the source of activity is deep in the profile. Cesium is probably readily exchanged between bark and wood just as potassium is. The gradient of cesium-137 in the bark with depth in Table 4.3 indicates that it is being exchanged with the wood. The other possible source would be contaminated leaves which might export cesium along with photosynthates translocated to the roots.

TABLE 4.3. Cesium-137 in the Wood and Bark of the Taproot and Lateral Roots of a Rabbitbrush Root System Collected from Excavation in Section II of the 216-A-24 Crib. Leaves of this plant (434) showed $5000 \mathrm{cpm}$ in the field survey and $320 \mathrm{nCi}{ }^{137} \mathrm{Cs}$ per gDW.

\begin{tabular}{|c|c|c|c|c|c|}
\hline \multicolumn{6}{|c|}{${ }^{137} \mathrm{Cs} \quad(\mathrm{nCi} / \mathrm{gDW})$} \\
\hline \multirow{3}{*}{$\begin{array}{l}\text { Depth } \\
(\mathrm{cm}) \\
\end{array}$} & \multicolumn{2}{|c|}{ Taproot } & \multirow{2}{*}{$\begin{array}{l}\text { Depth } \\
(\mathrm{cm})\end{array}$} & \multirow{2}{*}{$\frac{\text { Latera }]}{\text { Wood }}$} & \multirow{2}{*}{$\frac{\text { Roots }}{\text { Bark }}$} \\
\hline & Wood & Bark & & & \\
\hline & & & 12 & 18 & 33 \\
\hline \multirow[t]{2}{*}{$16-48$} & 40 & 96 & 16 & 9.3 & 20 \\
\hline & & & 48 & 22 & 53 \\
\hline $57-83$ & 44 & 160 & & & \\
\hline \multirow[t]{3}{*}{$112-158$} & 101 & 270 & & & \\
\hline & & & 163 & 45 & 170 \\
\hline & & & 181 & 52 & 150 \\
\hline \multirow[t]{2}{*}{$187-224$} & 93 & 250 & & & \\
\hline & & & 224 & 93 & 250 \\
\hline
\end{tabular}

TABLE 4.4. Cesium-137 in the Wood and Bark of the Taproot and Lateral Roots of a Rabbitbrush Root System Collected from Excavation in Section II of the 216-A-24 Crib. Leaves of this plant (446) showed $<200 \mathrm{cpm}$ (background) in the field survey and $2.3 \mathrm{nCi}{ }^{137} \mathrm{Cs} / \mathrm{gDW}$.

$$
\left.{ }^{137} \mathrm{Cs} \text { ( } \mathrm{nC} / \mathrm{gDW}\right)
$$

Depth

$\frac{(\mathrm{cm})}{50-60}$

$\begin{array}{ll}\frac{\text { Wood }^{\text {Taproot }}}{0.59} & \text { Bark } \\ 0.85 & \\ 0.6 & 3.0\end{array}$

$\frac{\begin{array}{l}\text { Depth } \\ (\mathrm{cm})\end{array}}{75}$

Lateral Roots

75-87

0.85

3.0

87

87 Wood Bark

2.0

5.8

0.58

2.4

0.92

3.9 


\section{RADIONUCLIDES IN SELECTED SOIL, PLANT, AND ANIMAL SAMPLES}

A number of biological, litter, and soil samples were taken from Section II of the Crib for the following purposes:

- to measure radionuclides in rabbitbrush leaves along the center of the Crib to determine whether the same nuclides are involved over the length of the Crib;

- to determine the location within the plant of the greatest concentration of radioactivity;

- to determine the potential for contamination of surface soils through annual 1 itterfall beneath rabbitbrush plants; and

- to determine whether animals on the Crib contain measurable quantities of radionuclides from consumption of contaminated leaves or other materials.

To accomplish the first of these objectives, leaves from 32 plants in the center of the mapped area of the Crib were collected along a transect chosen to be directly over the buried drainpipe. These leaves were submitted for gamma energy analyses and for ${ }^{90} \mathrm{Sr}$ analyses. Results are given in Appendix III.

This table shows that the principal radionuclide involved is ${ }^{137} \mathrm{Cs}$ which has an average value of $145 \mathrm{nCi} / \mathrm{gDW}$ for the 32 samples along the transect. Actual values range from "not detectable" to $891 \mathrm{nCi} / \mathrm{gDW}$. Throughout the length of the transect there were samples which showed detectable amounts of ${ }^{144} \mathrm{Ce},{ }^{106} \mathrm{Ru},{ }^{95} \mathrm{Zr}$, and ${ }^{54} \mathrm{Mn}$, but concentrations were so low when compared to levels of ${ }^{137} \mathrm{Cs}$ that precise measurement with the counting and spectrum stripping techniques used was impractical.

Levels of ${ }^{90} \mathrm{Sr}$ were nearly three orders of magnitude less than those for ${ }^{137} \mathrm{Cs}$. The average value over the transect was $0.316 \mathrm{nCi} 90 \mathrm{Sr} / \mathrm{qD} !$. Generally speaking, samples with high levels of ${ }^{137} \mathrm{Cs}$ have high levels of $90 \mathrm{Sr}$. The average value for the ratio of cesium to strontium concentration is 1500 . The same radionuclides occur along the length of the transect.

To accomplish the second objective, a single shrub (number 191, which showed $20,000 \mathrm{cpm}$ in the field survey) was removed to the laboratory and dissected into shoot parts (leaves, twigs, bark, wood) and roots (bark and wood). Results are given in Table 5.1 for radiocesium concentrations in these plant parts. Shoots show higher concentrations than roots and the highest concentrations are in the leaves. 
TABLE 5.1. Radiocesium in Parts of a Contaminated

Rabbitbrush Plant from the 216-A-24

Crib.

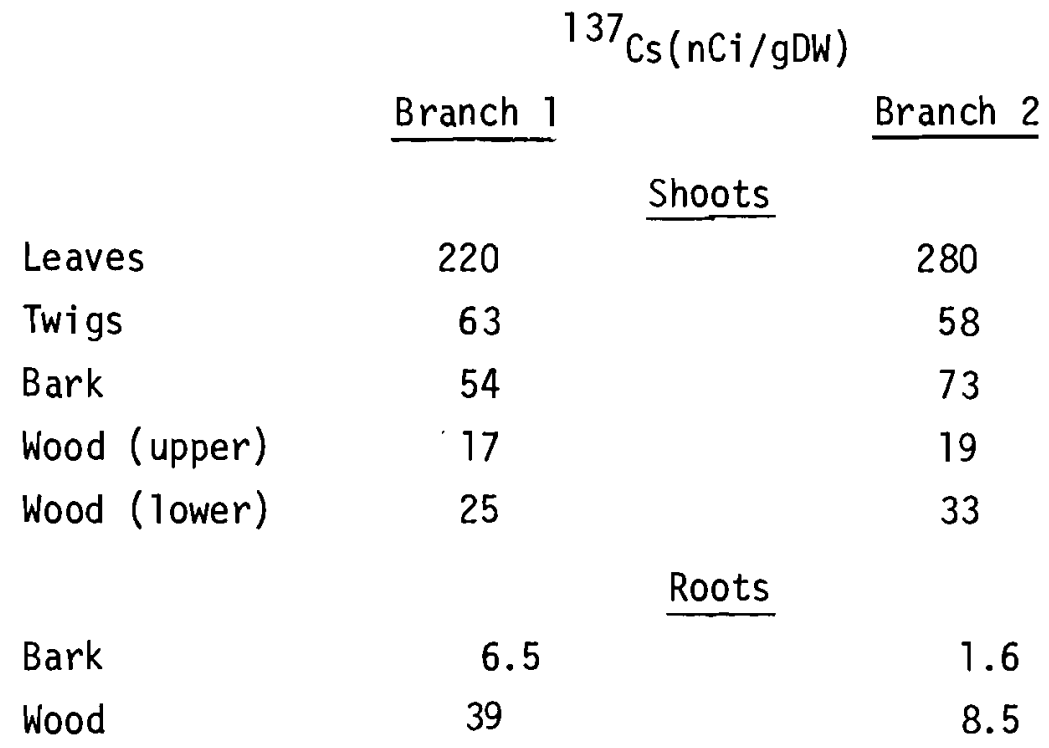

To accomplish the third objective, six rabbitbrush plants showing different levels of activity were selected. For these six shrubs, samples were taken of leaves, cheatgrass growing beneath the canopy, litter beneath the canopy, the upper $\mathrm{cm}$ of mineral soil beneath the litter, soil at the $15 \mathrm{~cm}$ depth, and rabbitbrush roots at the $15 \mathrm{~cm}$ depth. Also samples of cheatgrass and underlying surface soils as well as bare soils between rabbitbrush plants were collected. These samples were counted for ${ }^{137} \mathrm{Cs}$ content. Results are shown in Table 5.2.

In general, plants with highest levels of ${ }^{137} \mathrm{Cs}$ in this year's leaves had the highest levels of ${ }^{137} \mathrm{Cs}$ in litter, cheatgrass, surface soils, and rabbitbrush roots at the $15 \mathrm{~cm}$ depth. In no case was there significant activity in soil samples taken at the $15 \mathrm{~cm}$ depth.

Cheatgrass samples taken from between shrubs were almost invariably less contaminated than were similar samples taken from beneath shrub canopies. Samples of the upper $\mathrm{cm}$ of soil taken in unvegetated areas (bare soi1) and under uncontaminated rabbitbrush canopies were not contaminated. However, detectable levels were found in surface soils taken from beneath the cheatgrass swards sampled between shrubs even though the newly grown cheatgrass leaves were not notably contaminated. Apparently, cheatgrass swards have captured some wind-borne materials from nearby contaminated plants and from worldwide fallout causing some ${ }^{137} \mathrm{Cs}$ to accumulate in the upper $\mathrm{cm}$ of soil. 
TABLE 5.2. Cesium-137 in Plant and Soil Samples

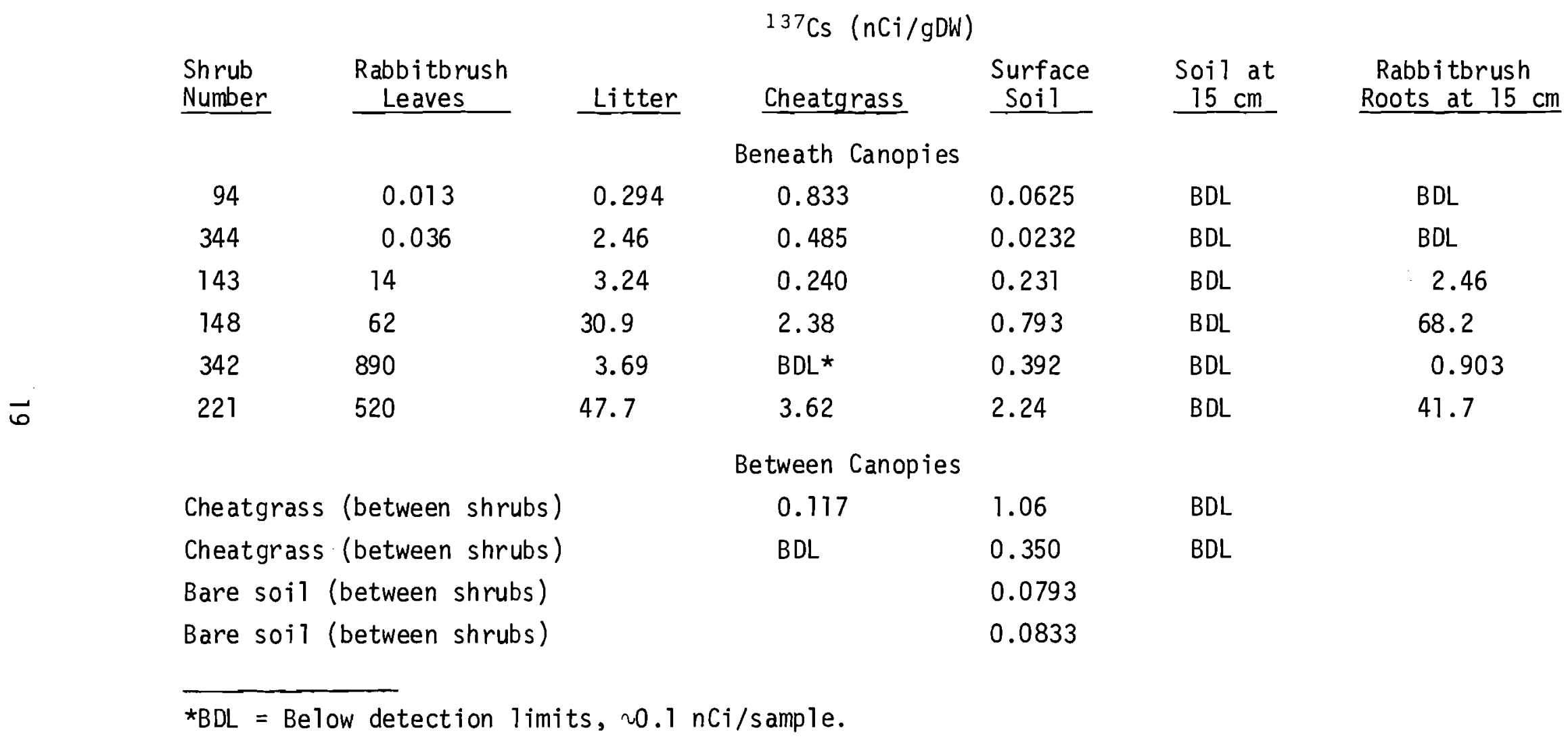


To accomplish the fourth objective, a number of animal samples were collected. These included invertebrates associated with rabbitbrush plants and those caught in pitfall traps and by hand, seven pocket mice, and all of the rabbit fecal pellets from the west half of the mapped area ( $12 \mathrm{x}$ 22 meters). The fecal pellets were ground and composited into a single large sample which was subsequently subsampled for radiochemical analysis.

Radiocesium concentrations for insects associated with rabbitbrush plants were higher than those collected either by hand or from pitfall traps (Table 5.3). The average value for the eight shrub-associated species was $16.3 \mathrm{nCi} / \mathrm{gDW}$, ranging from 1.9 to $71.5 \mathrm{nCi} / \mathrm{gDW}$.

of the seven mice analyzed, two had ${ }^{137}$ Cs levels significantly above background (Table 5.4). These two mice were dissected into hide, muscle and skeleton, and gut and these components analyzed separately. Results in Table 5.5 indicate that $12.3 \%$ of the ${ }^{13} 7 \mathrm{Cs}$ was in the hide, $69.5 \%$ in the muscle and bone, and $18.2 \%$ in the gut.

Rabbit pellets had an average value of $0.21 \mathrm{nCj}{ }^{137} \mathrm{Cs} / \mathrm{gDW}$. Since rabbits have rather large ranges, the source of the cesium in these pellets is uncertain. 


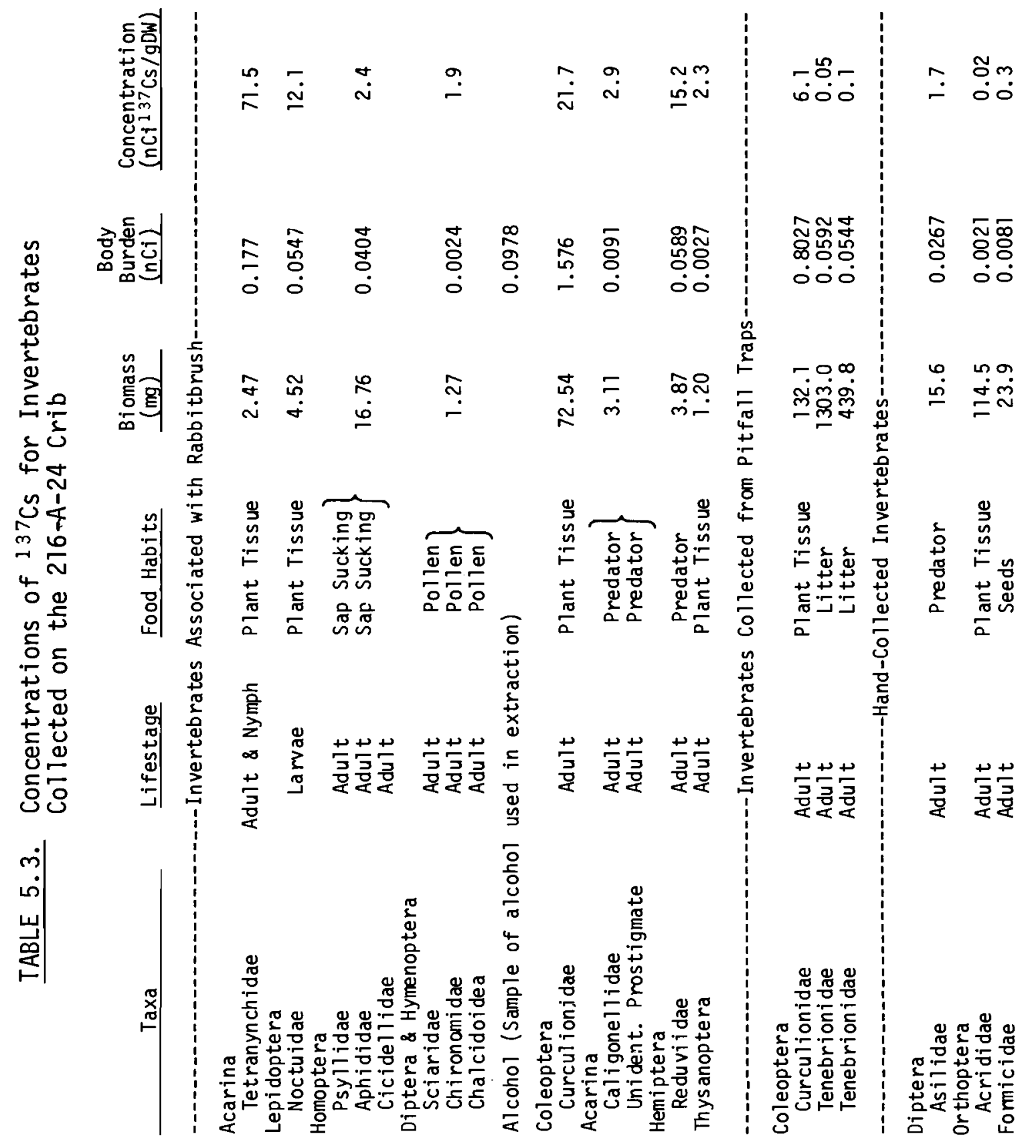




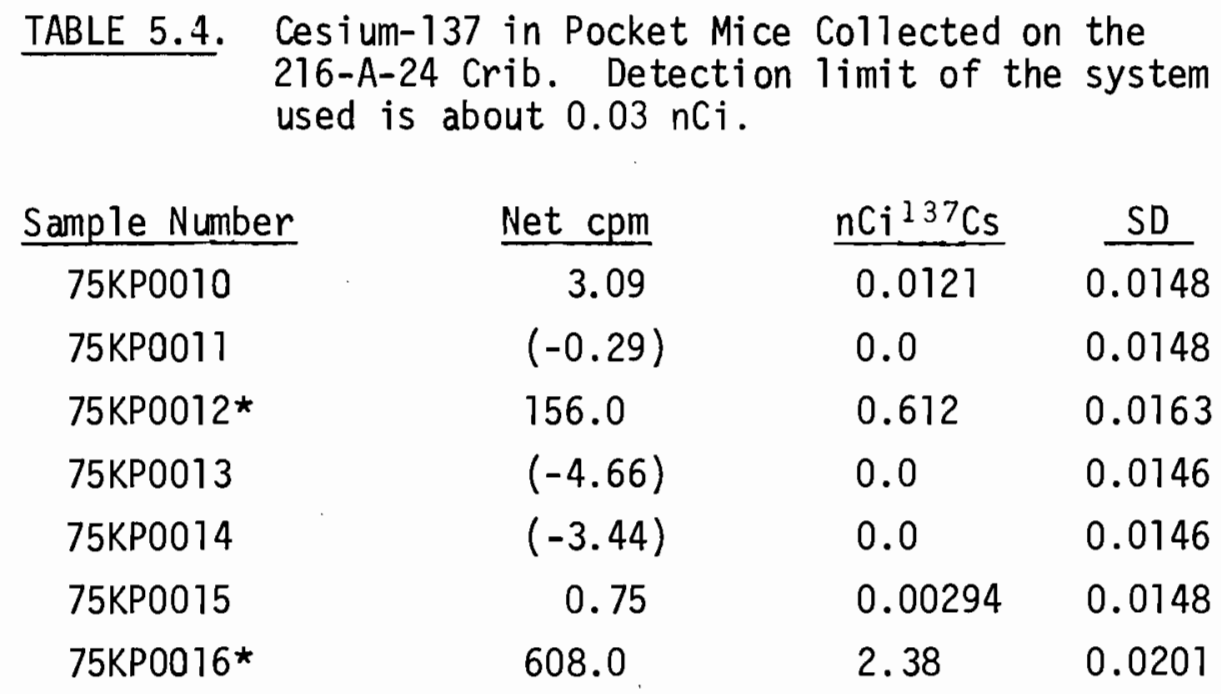

*Statistically significant

TABLE 5.5. Radiocesium Levels in Dissected Components of Two Contaminated Pocket Mice Captured on the 216-A-24 Crib

\begin{tabular}{|c|c|c|c|c|}
\hline & Net cpm & $\underline{\mathrm{nCi}}{ }^{137} \mathrm{Cs}$ & $\begin{array}{l}\text { Standard } \\
\text { Deviation }\end{array}$ & $\begin{array}{c}\% \text { of Total Body } \\
\text { Burden }\end{array}$ \\
\hline \multicolumn{5}{|l|}{$75 \mathrm{KP0012}$} \\
\hline Hide & 15.2 & 0.0595 & 0.0148 & 9.9 \\
\hline $\begin{array}{l}\text { Muscle and } \\
\text { skeleton }\end{array}$ & 111.3 & 0.4357 & 0.0158 & 72.6 \\
\hline Gut & 26.7 & 0.1047 & 0.0149 & 17.5 \\
\hline & & $=0.5999 \mathrm{nCi}$ & & \\
\hline \multicolumn{5}{|l|}{$75 \mathrm{KP} 0016$} \\
\hline Hi de & 88.7 & 0.3448 & 0.0167 & 14.8 \\
\hline $\begin{array}{l}\text { Muscle and } \\
\text { skeleton }\end{array}$ & 399.1 & 1.5518 & 0.0380 & 66.5 \\
\hline Gut & 112.7 & 0.4382 & 0.0318 & 18.7 \\
\hline
\end{tabular}




\section{DISCUSSION OF RESULTS}

Radioactivity associated with rabbitbrush plants on the $216-\mathrm{A}-24$ Crib is primarily $137 \mathrm{Cs}$. Leaves contained higher concentrations of ${ }^{137} \mathrm{Cs}$ than other plant parts. Concentrations of ${ }^{137} \mathrm{Cs}$ in leaves averaged $145 \mathrm{nCi} / \mathrm{gDW}$ and those for ${ }^{90} \mathrm{Sr}$ averaged $0.316 \mathrm{nCi} / \mathrm{gDW}$. Sand from the gravel layer in the first section of the $\mathrm{Crib}$ had $3.0 \mathrm{nCi}{ }^{137} \mathrm{Cs} / \mathrm{gDW}$. and $0.0259 \mathrm{nCi} 90 \mathrm{Sr} / \mathrm{gDW}$. Using these values for substrate and leaf concentrations, a concentration factor (c.f.) of 48.7 for ${ }^{137} \mathrm{Cs}$ and 12.2 for ${ }^{90} \mathrm{Sr}$ can be calculated.

Routson (Routson, 1975) found that tumbleweed seedlings grown for. 12 weeks in pots in growth chamber experiments have concentration factors of 0.053 for ${ }^{137} \mathrm{Cs}$ and 19 for ${ }^{90} \mathrm{Sr}$. Thus, the values calculated from data in this report are in agreement with Routson's values for $90 \mathrm{Sr}$, but are three orders of magnitude higher than his values for ${ }^{137} \mathrm{Cs}$. Of course, the two plant species may have different cesium affinities; there are no C.F. values available for rabbitbrush. Also, it is possible that roots may have penetrated deeper in the profile than the level of excavation and sampling. At deeper leve1s, ${ }^{137} \mathrm{Cs}$ content would probably be much higher than that of the material sampled from above the drainpipe so that concentration factors calculated would be considerably reduced.

While the facility was operating, water percolated downward from the drainpipe and carried cesium and strontium downward in the profile. Because of differences in behavior of these two radionuclides in soil, we would expect radiocesium to be held in the root zone to a greater extent than strontium. Thus, although cesium is discriminated against by most plants, the relative concentration of $137 \mathrm{Cs}$ in the root zone may be sufficiently great to cause cesium concentrations in leaves to equal or exceed the strontium levels.

The fact that there is considerable activity associated with the gravel is worth noting. The cesium may be taken up into such components of the gravel as mica. It is not known whether plants are absorbing cesium from the gravel or from soil between gravel pieces.

The distribution of ${ }^{137} \mathrm{Cs}$ in the bark and wood of these rabbitbrush plants is similar to distributions found for potassium in willow stems (Stout and Hoagland, 1939). In willow, $42 \mathrm{~K}$ readily exchanged between wood and bark but did not move readily in the phloem (bark). In the present investigation, concentrations and vertical gradients of ${ }^{137} \mathrm{Cs}$ in the bark were related to the values in the adjacent wood. Assuming that cesium does not move readily in phloem of rabbitbrush plants, one would expect it to build up in the leaves over the growing season so that values of the C.F. would be seasonally dependent. 
We do not know why the population of rabbitbrush is most dense and shows the highest levels of activity on the second section of the crib. It appears, though, that the high level of activity results from the fact that the average rooting depth is greater in this dense stand than it is on other parts of the crib.

The environmental factor most probably responsible for the dense and presumably deep-rooted stand is a greater and deeper supply of soil moisture. Several characteristics of the Crib surface are favorable for water accumulation. Chief among these are the presence on the surface of large cobbles which both increase runoff into depressions and decrease plant cover and the presence of unvegetated roads. A complete plant cover would more effectively use annual precipitation through root uptake and plant transpiration. The presence of channels open to the surface in certain dead ant nests could carry water to depth without saturating upper layers and thus contribute to deep supplies of moisture. The densest stand of rabbitbrush coincides with a depression in the landscape caused in part by a hill to the south. If rainfall and blowing snow are concentrated in this depression, then moisture would penetrate deeper in the profile and would encourage deep rooting of rabbitbrush plants.

This Crib has provided a unique opportunity to examine some aspects of radiocesium behavior in the 200 Area plateau. Data on food web transfers from mature leaves contaminated by plant uptake in the field are rare. Such data are expensive to obtain in the laboratory because of the long time required for producing mature plants. It would be valuable to sample during the summer to determine how plant uptake factors vary seasonally and to conduct some experiments on food web transfers of cesium. This site is especially important because the levels of interfering radionuclides are so 10 w that ${ }^{137} \mathrm{Cs}$ can be determined inexpensively without having to account for other isotopes such as ${ }^{90} \mathrm{Sr}$. 


\section{RECOMMENDATIONS}

Rabbitbrush plants need to be eradicated from the crib surface. The radioactive material from the central 12 meters of the second section probably should be removed for disposal. This material includes rabbitbrush plants, litter, and cheatgrass. The surface centimeter of soil could be scraped off the central 12 meters, but this may not be necessary since activity levels are quite low (see Table 5.2). Subsurface soils do not need to be removed. Rabbitbrush plants outside the central strip could be burned since they contain no detectable activity.

In order to prevent the sprouting of rabbitbrush from buds on the stumps, it would be advisable to spray the plants with a herbicide prior to the eradication. This will kill the buds which would produce sprouts.

Restoration of the surface can be made by scraping the cobble layer from the surface and replacing it with a one-foot layer of clean soil. The depression in the center of the Crib can be filled in by bulldozing onto the Crib surface the hill of unused backfill materials located to the south. Clean surface soil is also available from the area to the south. This filling and revegation could most effectively be done in 0ctober when natural rainfall would help prevent wind erosion and would promote germination of cheatgrass seed. A mulch of straw and bentonite and a dressing of fertilizer on the surface soil would be helpful in establishing cheatgrass during the first year. The stand should maintain itself after it has become established. Finally, an effort should be made to keep road traffic off of the new surface so that the plants can maintain a good cover.

We believe that there would be an advantage in permitting this crib to be used as a study area prior to restoration (see previous page). 
PHOTOGRAPHS 


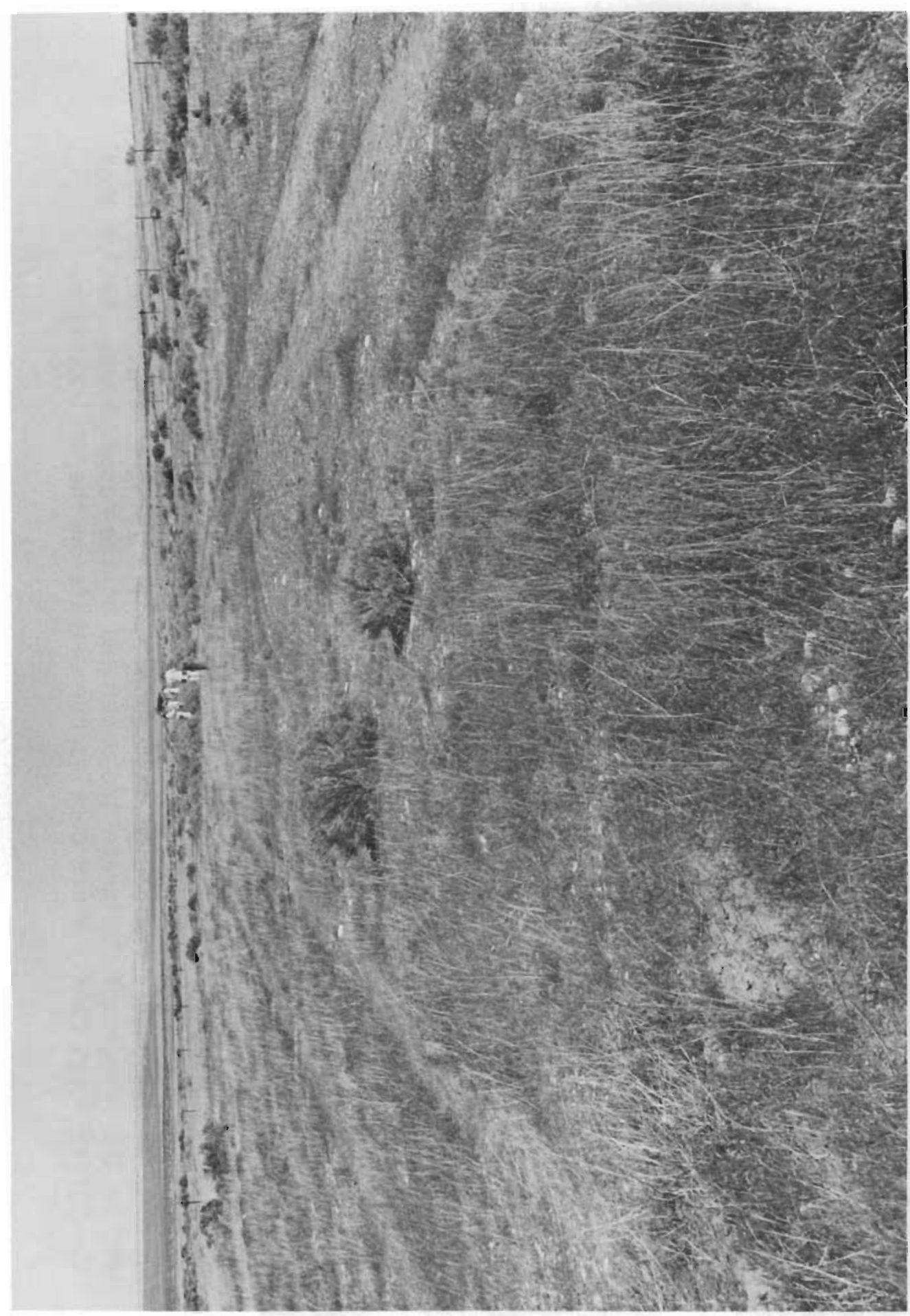

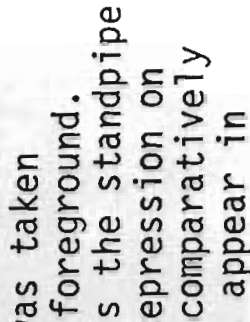

3 웜 थ

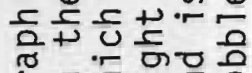

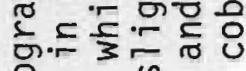

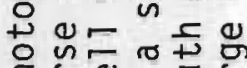

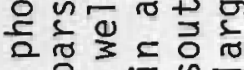

a nor

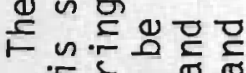
웅이

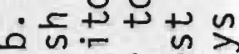
ट

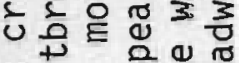

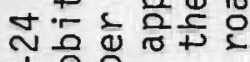

100

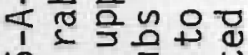

6 ब $\vec{\imath}>+$

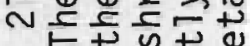

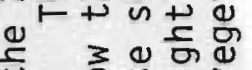

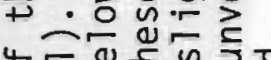

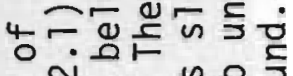

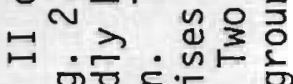

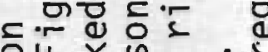

으는둥

开

\&

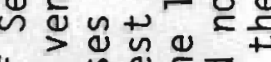

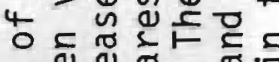

ब ष

3 a 2

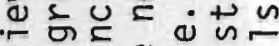

$>$. 000

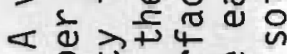

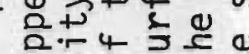

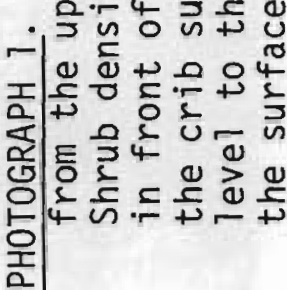




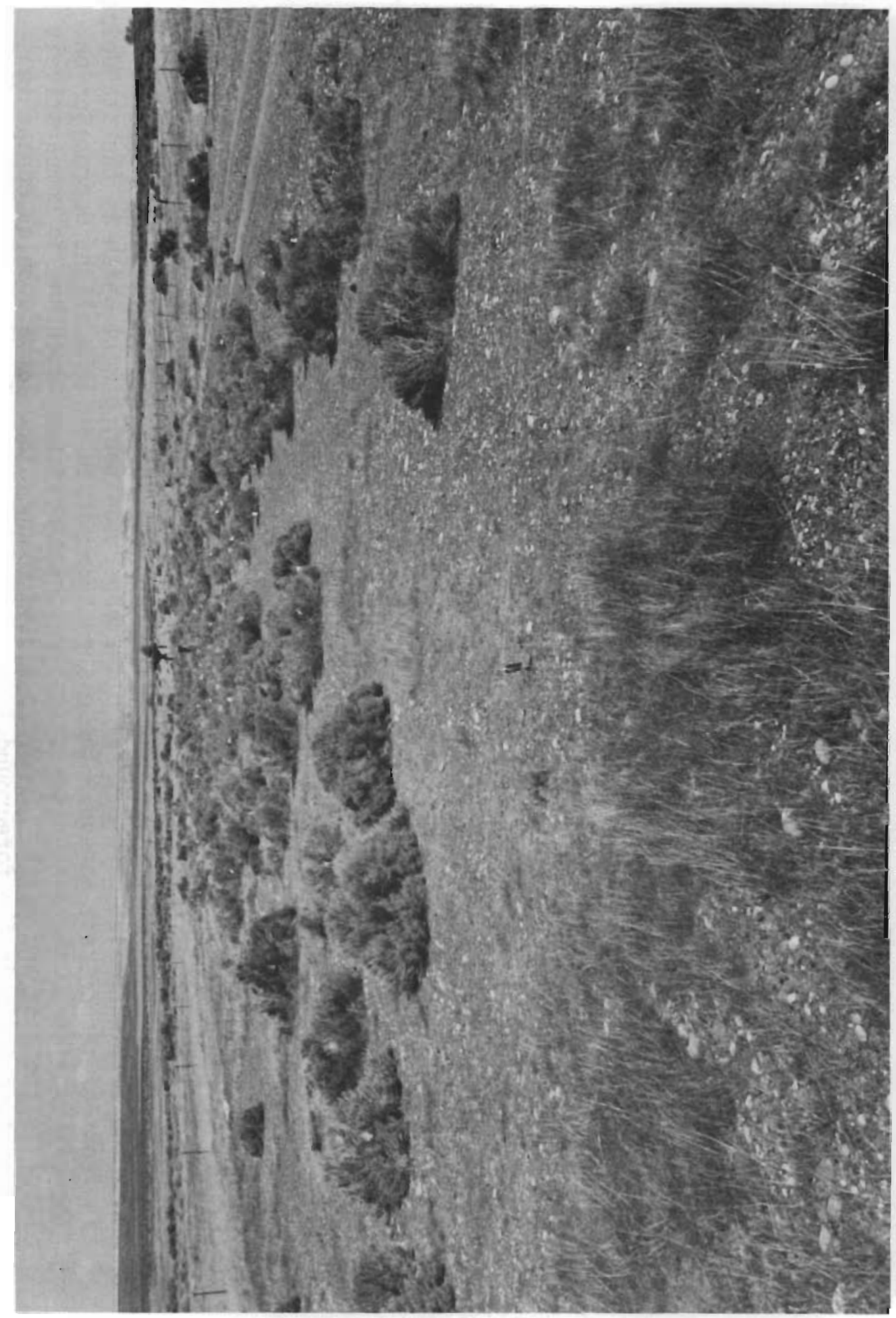

ֻู ญ

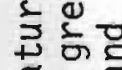

造㐫 亩

능몽

도웡

원

만융

干

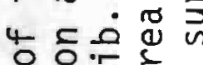

은

웡요

+ is

\&

叫语

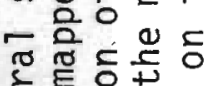

$\zeta$ 어

प्र य政 뜬 뜬 = 드용 언 윽

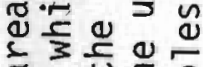

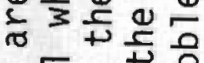
듕ㄷㅇㅇㅇㅇ

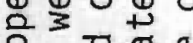
응뭉

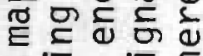
的 ब is 돈엉

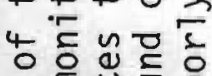
일웡ㅇㅇㅇ 娄与 0 $>\frac{1}{3} \cdot 5$ $<$ 으 ڤ)

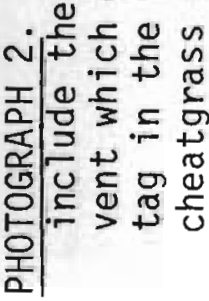




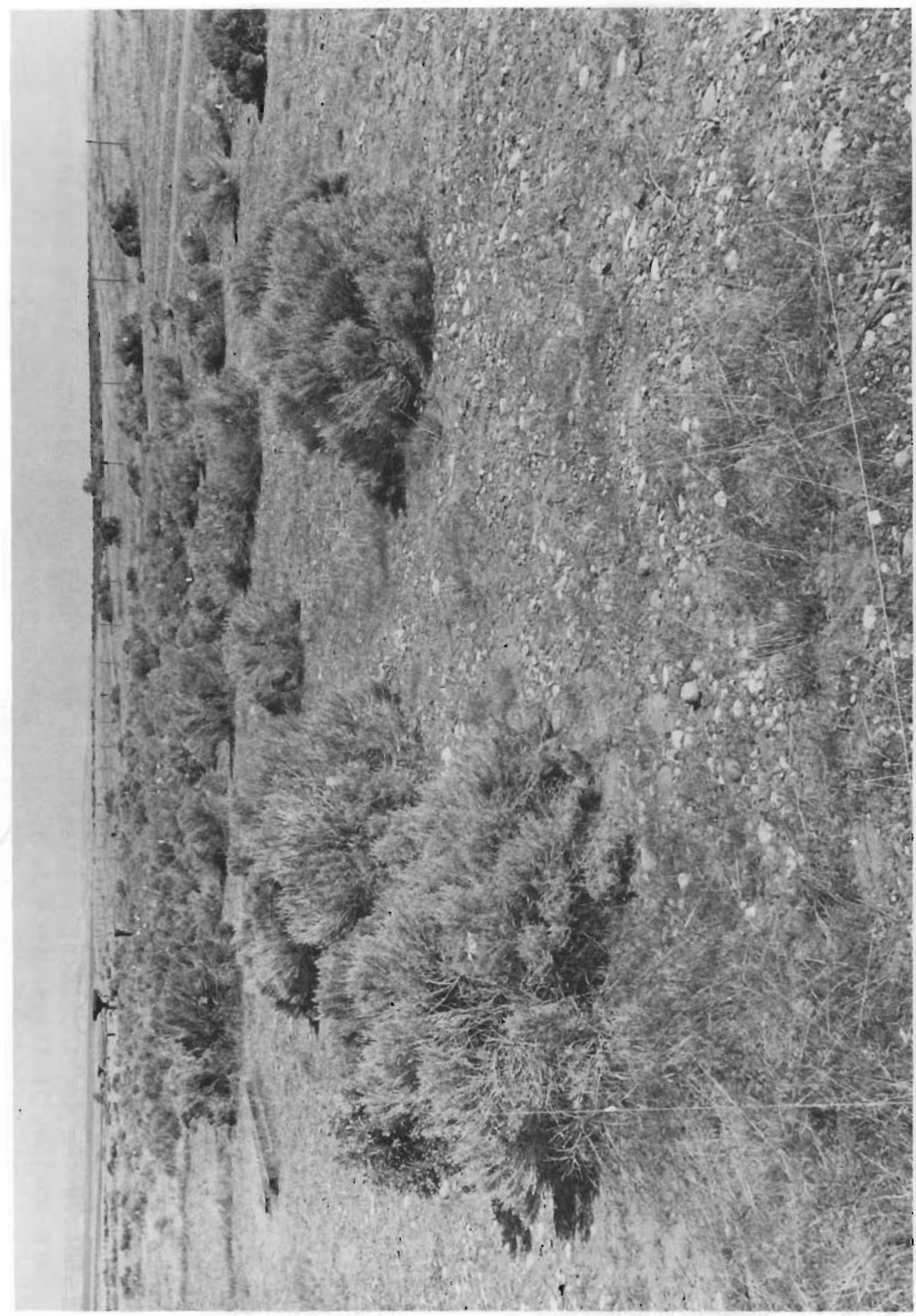

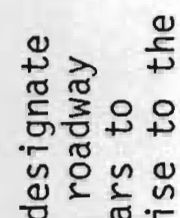

\%

舟市응

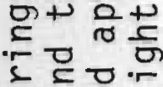

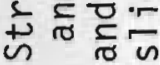

专西

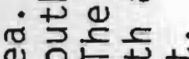

记 3 응

어ㅇㅝㅓ

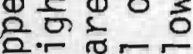

तै

E Q 中 $4+0$

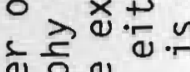

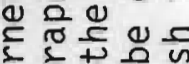

ㄷํㄴ든

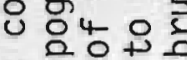
+ 응 $0+1$ 为 है סृष्ठ in +5 든 55 \& 8. 엄

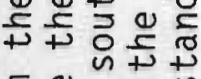
틍 웡요 4 $4-4$ з은 믿줨 () ᄃㅇㅇㅇ $>$.

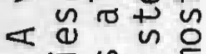
- थ

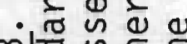
m| 동ํํㅇ 这告 응 응 $\frac{\pi}{=} \frac{c}{3}=$ 


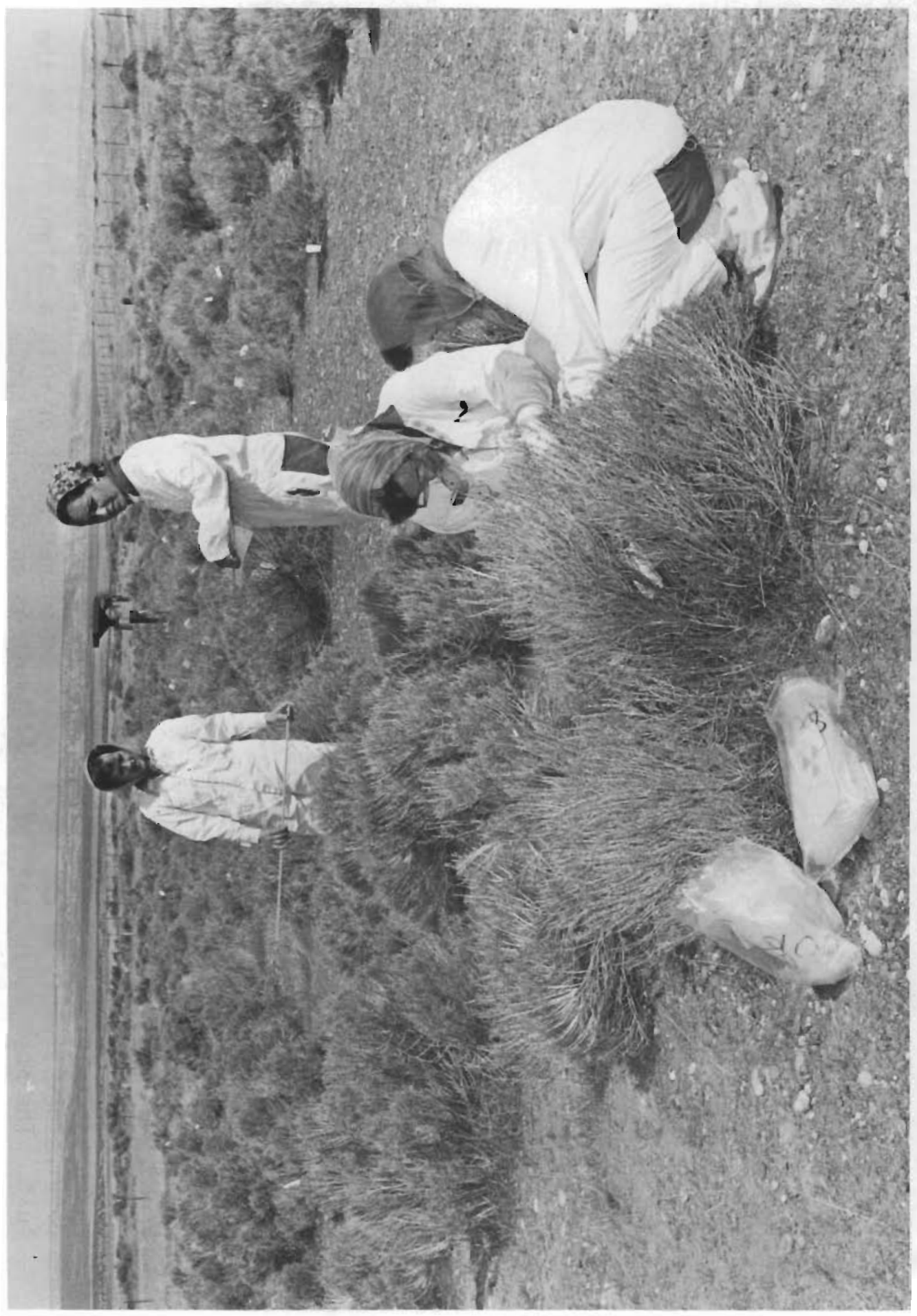

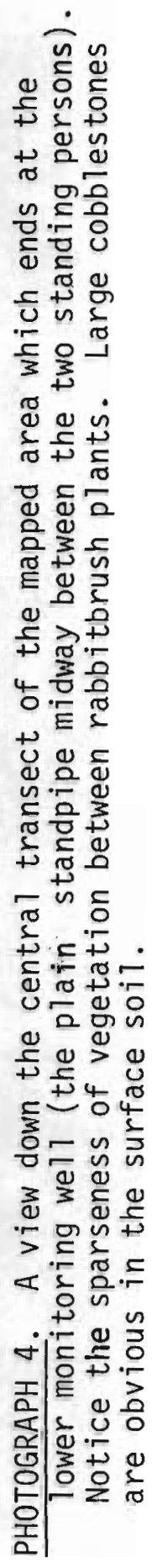



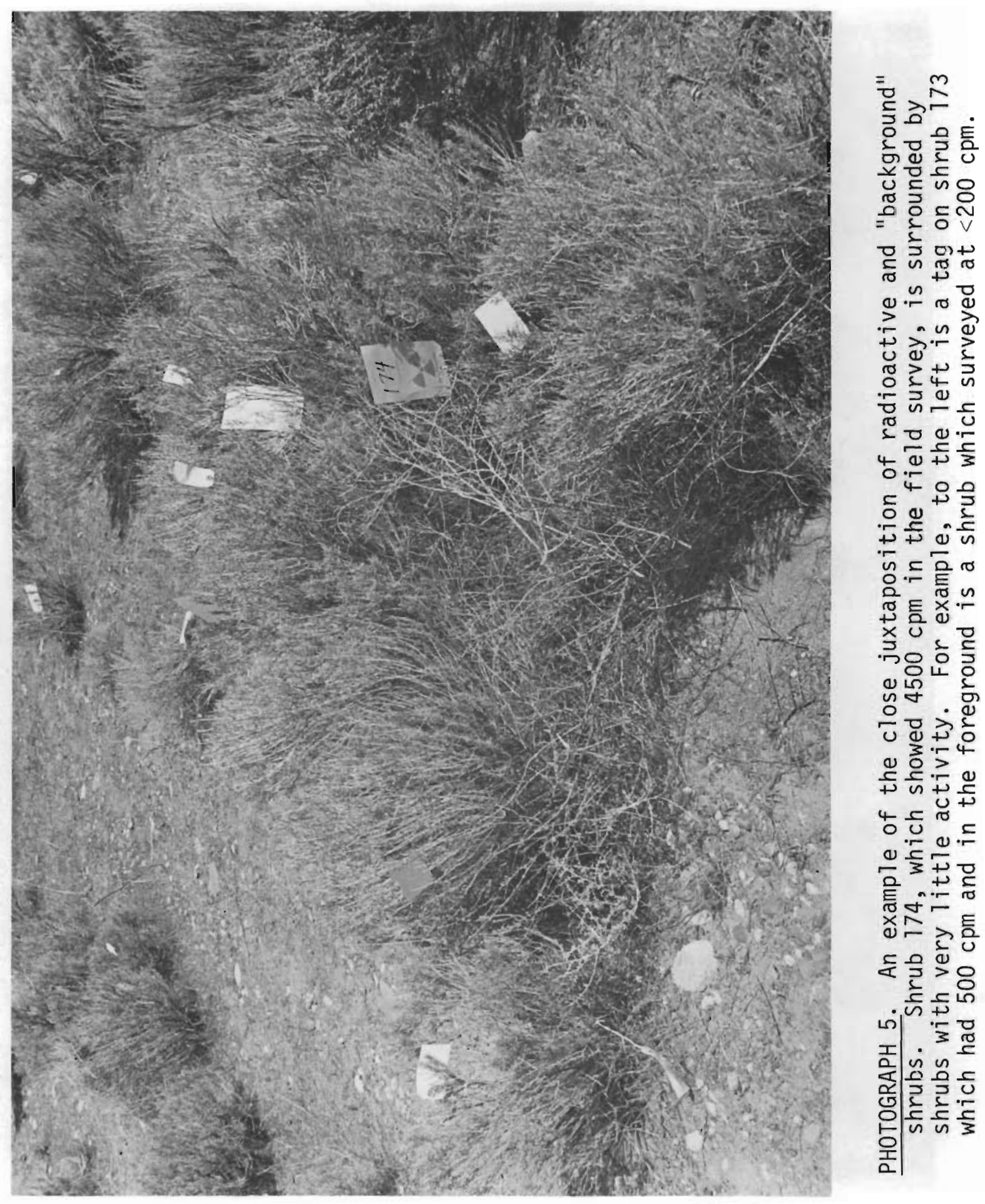


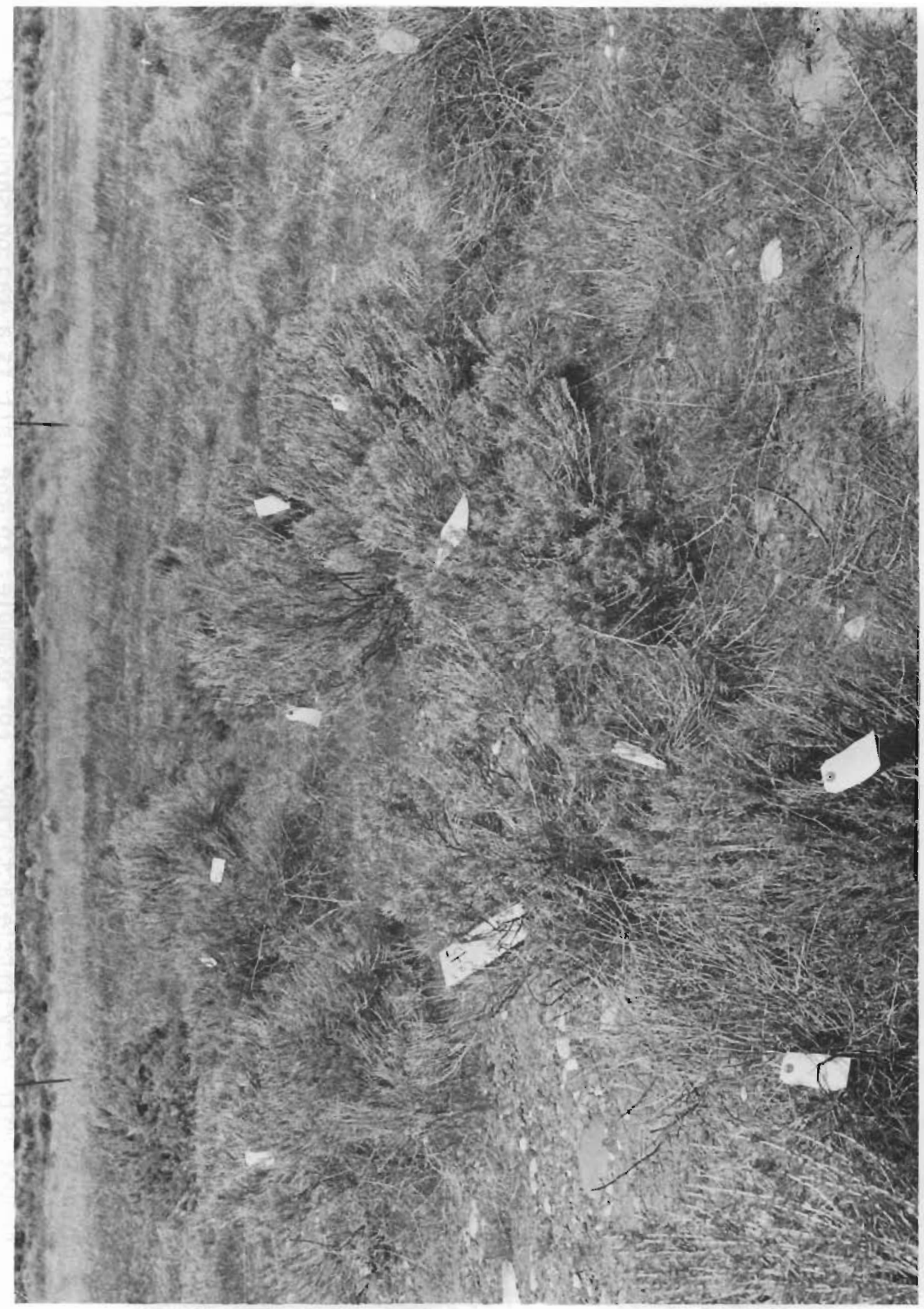

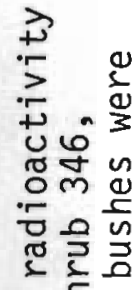

4 兵白

(등

Uั

당

के

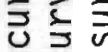

जे

Q 음 호

क $\frac{0}{4} 4$

40

的安远

)

$\stackrel{\varrho}{\complement} \cong$

흥틍 틍

잉

180

뉴

व

월

드을

๕๐

+

4 宁范

읕

骨完它

일

ब 릴

运的至

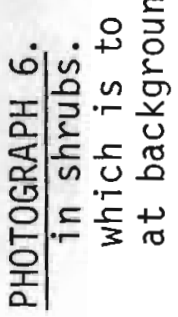




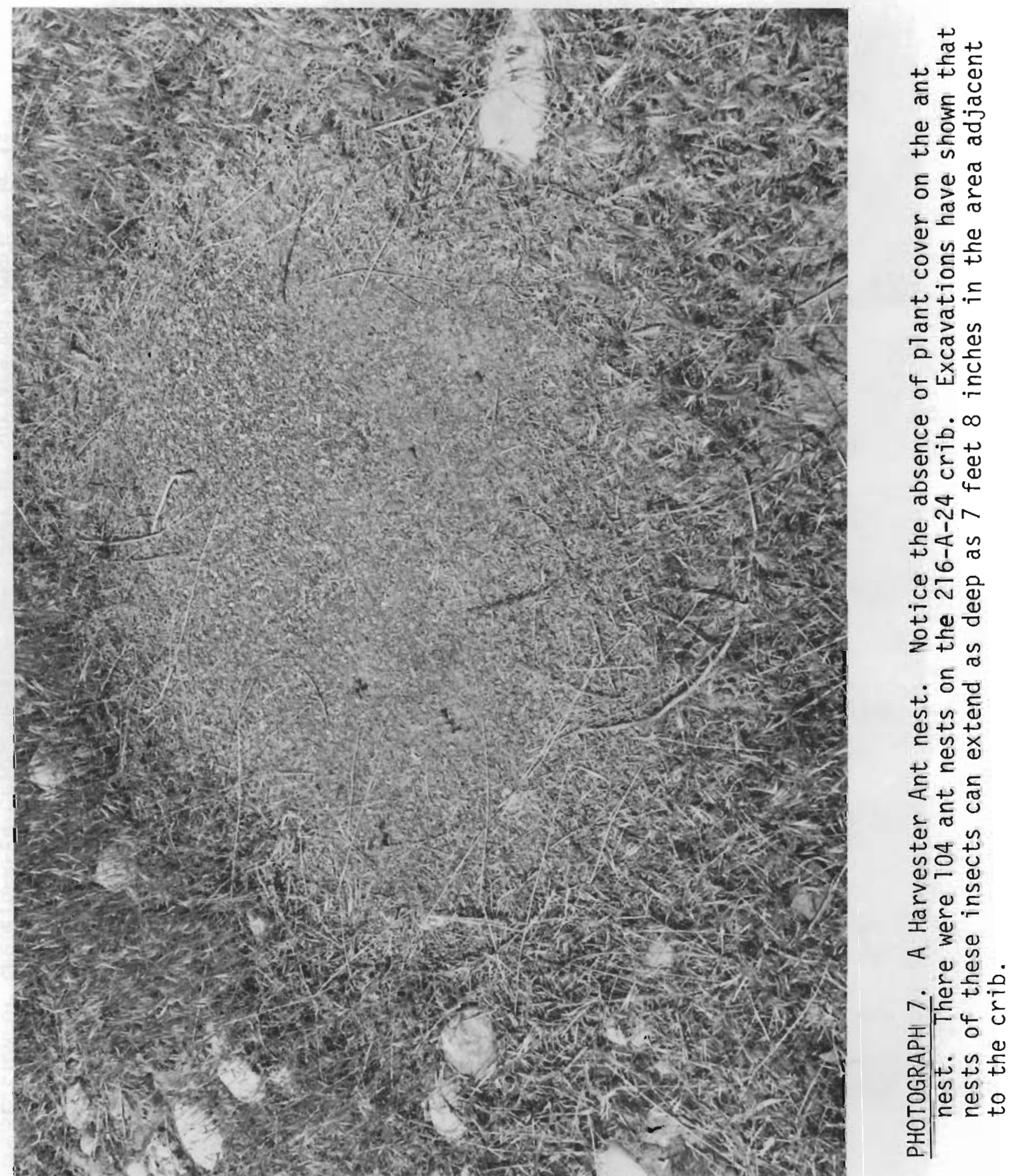




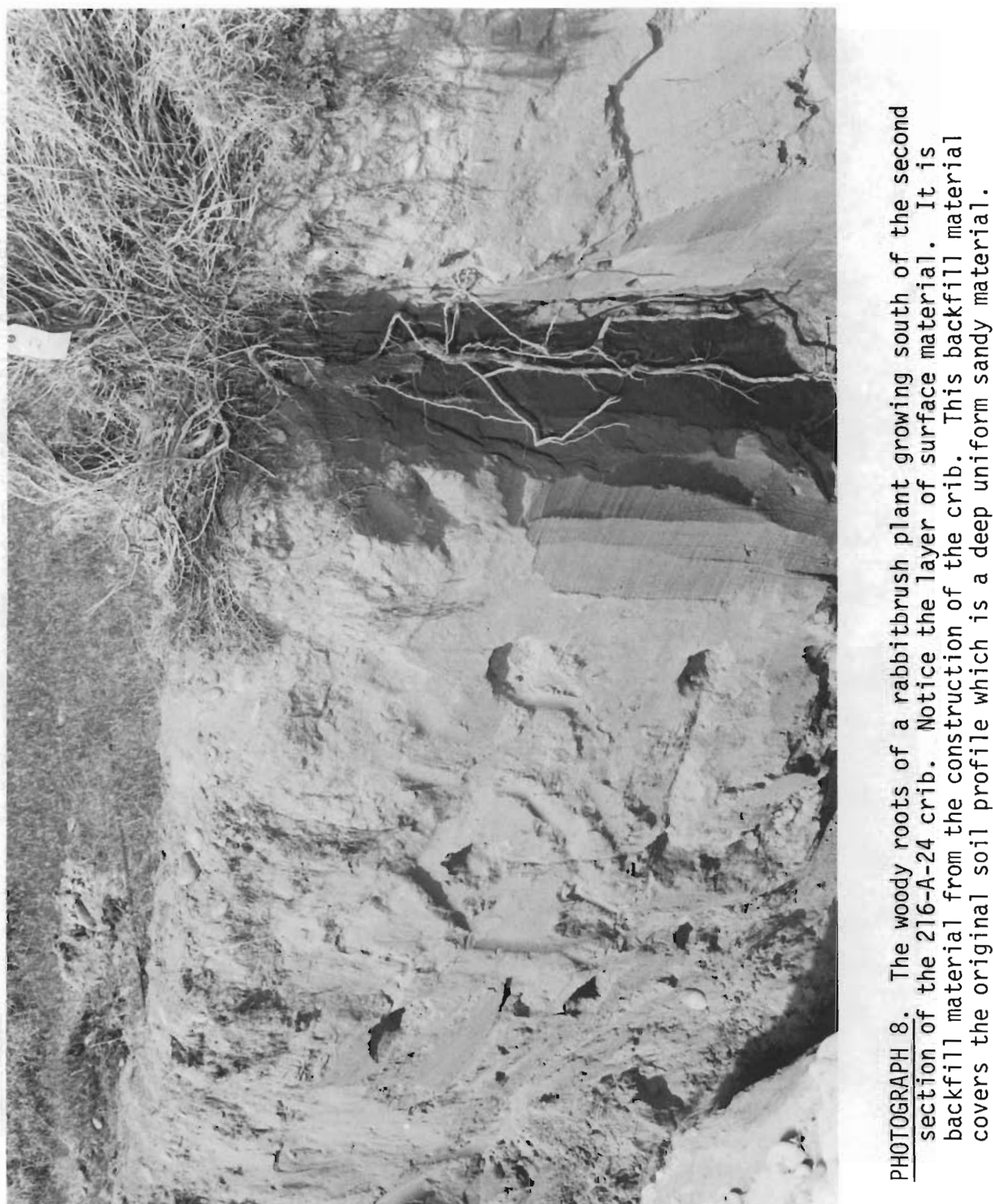




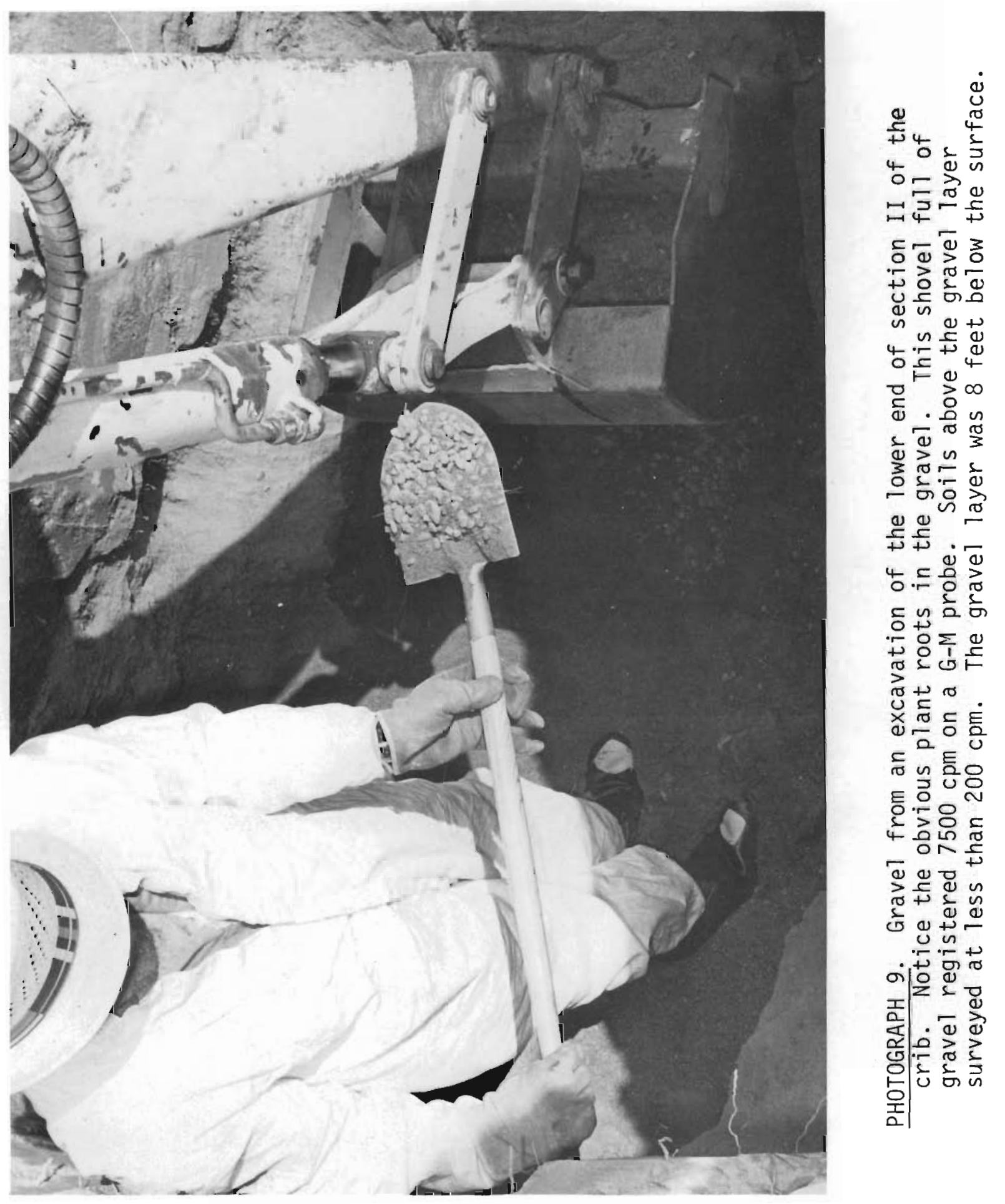




\section{I.TTERATURE CITED}

Anderson, J. D. 1975. Radioactive Liquid Wastes Discharged to Ground in the 200 Areas during 1974. ARH-3093 4Q.

Cline, J. F., D. W. Uresk, and W. H. Rickard. 1975. Characterization of Plant Communities adjacent to the B-C Cribs Controlled Area and REDOX

Pond Areas on the 200 Area Plateau. BNWL-1916.

Lundgren, L. L. 1970. 200 East and North Areas Radioactive Liquid Waste Disposal Sites. ARH-1562.

Routson, R. C. 1975. The Effect of Soil Concentration on the Tumbleweed Uptake of ${ }^{90} \mathrm{Sr}$ and $137 \mathrm{Cs}$ from a Burbank Sand. BNWL-1905.

Stout, P. R. and D. R. Hoagland. 1939. Amer. J. Bot. 26:320-324. 
APPENDICES 


\section{APPENDIX I}

Plant age and size as related to radioactivity in leaf tips. Plants were aged by counting annual rings on stem sections. Canopy volume was calculated from the formula, $(2 \pi / 3)[(h+0.5 w+0.51) / 3]^{3}$ on the assumption that the canopy is a hemisphere.

\begin{tabular}{|c|c|c|c|c|c|c|}
\hline \multirow{2}{*}{$\begin{array}{l}\text { Shrub } \\
\text { Number }\end{array}$} & \multicolumn{4}{|c|}{ Canopy Size } & \multirow{2}{*}{$\frac{\text { Age }}{(y r)}$} & \multirow{2}{*}{$\frac{\text { Radioactivity }}{\text { (cpm) }}$} \\
\hline & $\overline{h(c m)}$ & $w(\mathrm{~cm})$ & $1(\mathrm{~cm})$ & vol. $\left(m^{3}\right)$ & & \\
\hline 94 & 77 & 150 & 100 & 0.64 & 10 & $<200$ \\
\hline 142 & 74 & 105 & 70 & 0.33 & 9 & $<200$ \\
\hline 343(dead) & 56 & 76 & 56 & 0.14 & $(7)$ & $<200$ \\
\hline 344 & 55 & 42 & 34 & 0.06 & 8 & $<200$ \\
\hline 102 & 47 & 124 & 100 & 0.31 & 10 & 400 \\
\hline 118 & 74 & 120 & 100 & 0.48 & 11 & 400 \\
\hline 119 & 75 & 113 & 105 & 0.49 & 12 & 400 \\
\hline 95 & 68 & 120 & 110 & 0.47 & 9 & 600 \\
\hline 196 & 53 & 73 & 40 & 0.10 & 10 & 600 \\
\hline 147 & 47 & 60 & 30 & 0.06 & 9 & 750 \\
\hline 342 & 68 & 115 & 56 & 0.28 & 12 & 750 \\
\hline 143 & 67 & 80 & 72 & 0.23 & 9 & 1000 \\
\hline 295 & 74 & 80 & 68 & 0.25 & 11 & 1000 \\
\hline 106 & 67 & 100 & 80 & 0.30 & 6 & 1500 \\
\hline 124 & 71 & 115 & 86 & 0.39 & 11 & 1500 \\
\hline 120 & 88 & 115 & 113 & 0.65 & 9 & 2000 \\
\hline 192 & 56 & 58 & 54 & 0.11 & 10 & 2000 \\
\hline 341 & 75 & -- & -- & --- & 10 & 2000 \\
\hline 222 & 73 & 84 & 80 & 0.29 & 10 & 2500 \\
\hline 150 & 56 & 80 & 50 & 0.14 & 7 & 3000 \\
\hline 269 & 47 & 50 & 48 & 0.07 & 9 & 3000 \\
\hline 316 & 88 & 90 & 62 & 0.34 & 8 & 4000 \\
\hline 224 & 40 & 67 & 46 & 0.07 & 9 & 4500 \\
\hline 270 & 60 & 50 & 40 & 0.09 & 10 & 5000 \\
\hline 268 & 61 & 53 & 50 & 0.11 & 11 & 6500 \\
\hline 314 & 70 & 80 & 52 & 0.19 & 9 & 7000 \\
\hline 149 & 62 & 100 & 90 & 0.30 & 9 & 7500 \\
\hline 198 & 68 & 94 & 60 & 0.24 & 9 & 8000 \\
\hline 148 & 49 & 67 & 50 & 0.10 & 8 & 15000 \\
\hline 194 & 50 & 65 & 35 & 0.08 & 10 & 15000 \\
\hline 195 & 60 & 86 & 86 & 0.24 & 10 & 15000 \\
\hline 221 & 59 & 58 & 70 & 0.14 & 10 & 25000 \\
\hline
\end{tabular}




\section{APPENDIX II}

Levels of radioactivity in numbered shrubs on Section II of the 216-A-24 Crib. Numbering began at the western end of the crib. Numbers 1, 3, 14, 42, 44, 46, 51,61,78, 492, 502, 510, and 512 were sagebrush; a 11 others were rabbitbrush. Radioactivity measured as counts per minute with a G-M portable meter.

\begin{tabular}{|c|c|c|c|}
\hline $\begin{array}{l}\text { Plant } \\
\text { Number }\end{array}$ & $\begin{array}{l}\text { Counts Per } \\
\text { Minute }\end{array}$ & $\begin{array}{l}\text { Plant } \\
\text { Number }\end{array}$ & $\begin{array}{c}\text { Counts Per } \\
\text { Minute }\end{array}$ \\
\hline 1 & $<200$ & 26 & $<200$ \\
\hline 2 & $<200$ & 27 & $<200$ \\
\hline 3 & $<200$ & 28 & $<200$ \\
\hline 4 & $<200$ & 29 & $<200$ \\
\hline 5 & $<200$ & 30 & $<200$ \\
\hline 6 & $<200$ & 31 & $<200$ \\
\hline 7 & $<200$ & 32 & $<200$ \\
\hline 8 & $<200$ & 33 & $<200$ \\
\hline 9 & $<200$ & 34 & $<200$ \\
\hline 10 & $<200$ & 35 & $<200$ \\
\hline 11 & $<200$ & 36 & $<200$ \\
\hline 12 & $<200$ & 37 & $<200$ \\
\hline 13 & $<200$ & 38 & $<200$ \\
\hline 14 & $<200$ & 39 & $<200$ \\
\hline 15 & $<200$ & 40 & $<200$ \\
\hline 16 & $<200$ & 41 & $<200$ \\
\hline 17 & $<200$ & 42 & $<200$ \\
\hline 18 & $<200$ & 43 & $<200$ \\
\hline 19 & $<200$ & 44 & $<200$ \\
\hline 20 & $<200$ & 45 & $<200$ \\
\hline 21 & $<200$ & 46 & $<200$ \\
\hline 22 & $<200$ & 47 & $<200$ \\
\hline 23 & $<200$ & 48 & $<200$ \\
\hline 24 & $<200$ & 49 & $<200$ \\
\hline 25 & $<200$ & 50 & $<200$ \\
\hline
\end{tabular}




\begin{tabular}{|c|c|c|c|}
\hline $\begin{array}{l}\text { Plant } \\
\text { Number }\end{array}$ & $\begin{array}{c}\text { Counts per } \\
\text { Minutes } \\
\end{array}$ & $\begin{array}{l}\text { Plant } \\
\text { Number }\end{array}$ & $\begin{array}{c}\text { Counts per } \\
\text { Minute }\end{array}$ \\
\hline 51 & $<200$ & 86 & $<200$ \\
\hline 52 & $<200$ & 87 & $<200$ \\
\hline 53 & $<200$ & 88 & $<200$ \\
\hline 54 & $<200$ & 89 & $<200$ \\
\hline 55 & $<200$ & 90 & $<200$ \\
\hline 56 & $<200$ & 91 & 400 \\
\hline 57 & $<200$ & 92 & $<200$ \\
\hline 58 & $<200$ & 93 & $<200$ \\
\hline 59 & $<200$ & 94 & $<200$ \\
\hline 60 & $<200$ & 95 & 600 \\
\hline 61 & $<200$ & 96 & $<200$ \\
\hline 62 & $<200$ & 97 & $<200$ \\
\hline 63 & $<200$ & 98 & $<200$ \\
\hline 64 & $<200$ & 99 & $<200$ \\
\hline 65 & $<200$ & 100 & 300 \\
\hline 66 & $<200$ & 101 & 600 \\
\hline 67 & $<200$ & 102 & 400 \\
\hline 68 & $<200$ & 103 & $<200$ \\
\hline 69 & $<200$ & 104 & $<200$ \\
\hline 70 & $<200$ & 105 & $<200$ \\
\hline 71 & $<200$ & 106 & 1500 \\
\hline 72 & $<200$ & 107 & $<200$ \\
\hline 73 & $<200$ & 108 & $<200$ \\
\hline 74 & $<200$ & 109 & $<200$ \\
\hline 75 & $<200$ & 110 & $<200$ \\
\hline 76 & $<200$ & 111 & $<200$ \\
\hline 77 & $<200$ & 112 & $<200$ \\
\hline 78 & $<200$ & 113 & 1500 \\
\hline 79 & $<200$ & 114 & $<200$ \\
\hline 80 & 800 & 115 & $<200$ \\
\hline 81 & 1800 & 116 & $<200$ \\
\hline 82 & 1000 & 117 & $<200$ \\
\hline 83 & $<200$ & 118 & 400 \\
\hline 84 & $<200$ & 119 & 400 \\
\hline 85 & $<200$ & 120 & 2000 \\
\hline
\end{tabular}




\begin{tabular}{|c|c|c|c|}
\hline $\begin{array}{l}\text { P1ant } \\
\text { Number }\end{array}$ & $\begin{array}{c}\text { Counts per } \\
\text { Minute }\end{array}$ & $\begin{array}{l}\text { P1 ant } \\
\text { Number }\end{array}$ & $\begin{array}{c}\text { Counts per } \\
\text { Minute }\end{array}$ \\
\hline 121 & $<200$ & 156 & $<200$ \\
\hline 122 & $<200$ & 157 & $<200$ \\
\hline 123 & $<200$ & 158 & $<200$ \\
\hline 124 & 1500 & 159 & $<200$ \\
\hline 125 & 3000 & 160 & $<200$ \\
\hline 126 & $<200$ & 161 & $<200$ \\
\hline 127 & $<200$ & 162 & $<200$ \\
\hline 128 & $<200$ & 163 & $<200$ \\
\hline 129 & $<200$ & 164 & $<200$ \\
\hline 130 & $<200$ & 165 & $<200$ \\
\hline 131 & $<200$ & 166 & $<200$ \\
\hline 132 & $<200$ & 167 & $<200$ \\
\hline 133 & $<200$ & 168 & 1000 \\
\hline 134 & $<200$ & 169 & 800 \\
\hline 135 & 4000 & 170 & $<200$ \\
\hline 136 & 500 & 171 & $<200$ \\
\hline 137 & 300 & 172 & 500 \\
\hline 138 & $<200$ & 173 & 500 \\
\hline 139 & 25,000 & 174 & 4500 \\
\hline 140 & 20,000 & 175 & 5000 \\
\hline 141 & 20,000 & 176 & $<200$ \\
\hline 142 & $<200$ & 177 & $<200$ \\
\hline 143 & 1000 & 178 & 750 \\
\hline 144 & $<200$ & 179 & 1500 \\
\hline 145 & $<200$ & 180 & $<200$ \\
\hline 146 & 4000 & 181 & $<200$ \\
\hline 147 & 750 & 182 & $<200$ \\
\hline 148 & 15,000 & 183 & $<200$ \\
\hline 149 & 7500 & 184 & $<200$ \\
\hline 150 & 3000 & 185 & $<200$ \\
\hline 151 & $<200$ & 186 & 2500 \\
\hline 152 & 6000 & 187 & $<200$ \\
\hline 153 & $<200$ & 188 & $<200$ \\
\hline 154 & $<200$ & 189 & $<200$ \\
\hline 155 & $<200$ & 190 & $<200$ \\
\hline
\end{tabular}




\begin{tabular}{|c|c|c|c|}
\hline $\begin{array}{l}\text { Plant } \\
\text { Number }\end{array}$ & $\begin{array}{c}\text { Counts per } \\
\text { Minute }\end{array}$ & $\begin{array}{l}\text { Plant } \\
\text { Number }\end{array}$ & $\begin{array}{c}\text { Counts per } \\
\text { Minute }\end{array}$ \\
\hline 191 & 20,000 & 226 & 4000 \\
\hline 192 & 2000 & 227 & 2500 \\
\hline 193 & 1500 & 228 & 10,000 \\
\hline 194 & 15,000 & 229 & 1000 \\
\hline 195 & 15,000 & 230 & 4000 \\
\hline 196 & 600 & 231 & 4000 \\
\hline 197 & 2000 & 232 & $<200$ \\
\hline 198 & 8000 & 233 & 2000 \\
\hline 199 & $<200$ & 234 & $<200$ \\
\hline 200 & 3000 & 235 & $<200$ \\
\hline 201 & $<200$ & 236 & $<200$ \\
\hline 202 & $<200$ & 237 & $<200$ \\
\hline 203 & $<200$ & 238 & $<200$ \\
\hline 204 & $<200$ & 239 & $<200$ \\
\hline 205 & $<200$ & 240. & $<200$ \\
\hline 206 & $<200$ & 241 & $<200$ \\
\hline 207 & $<200$ & 242 & 1000 \\
\hline 208 & $<200$ & 243 & $<200$ \\
\hline 209 & $<200$ & 244 & $<200$ \\
\hline 210 & $<200$ & 245 & $<200$ \\
\hline 211 & $<200$ & 246 & 6000 \\
\hline 212 & 450 & 247 & $<200$ \\
\hline 213 & $<200$ & 248 & $<200$ \\
\hline 214 & $<200$ & 249 & 3500 \\
\hline 215 & $<200$ & 250 & 2000 \\
\hline 216 & $<200$ & 251 & $<200$ \\
\hline 217 & $<200$ & 252 & 1000 \\
\hline 218 & 400 & 253 & $<200$ \\
\hline 219 & 600 & 254 & 20,000 \\
\hline 220 & 7500 & 255 & $<200$ \\
\hline 221 & 25,000 & 256 & $<200$ \\
\hline 222 & 2500 & 257 & $<200$ \\
\hline 223 & 600 & 258 & $<200$ \\
\hline 224 & 4500 & 259 & $<200$ \\
\hline 225 & 1500 & 260 & $<200$ \\
\hline
\end{tabular}




\begin{tabular}{|c|c|c|c|}
\hline $\begin{array}{l}\text { Plant } \\
\text { Numbers }\end{array}$ & $\begin{array}{c}\text { Counts per } \\
\text { Minute }\end{array}$ & $\begin{array}{l}\text { Plant } \\
\text { Numbers }\end{array}$ & $\begin{array}{c}\text { Counts per } \\
\text { Minute }\end{array}$ \\
\hline 261 & 400 & 291 & 5000 \\
\hline 262 & 400 & 292 & 5000 \\
\hline 263 & $<200$ & 293 & 6500 \\
\hline 264 & $<200$ & 294 & 2500 \\
\hline 265 & 2200 & 295 & 1000 \\
\hline 266 & $<200$ & 296 & 2500 \\
\hline 267 & 2000 & 297 & $<200$ \\
\hline 268 & 6500 & 298 & 800 \\
\hline 269 & 3000 & 299 & 5000 \\
\hline 270 & 5000 & 300 & 700 \\
\hline 271 & 3000 & 301 & $<200$ \\
\hline $271 \mathrm{~A}$ & 6000 & 302 & $<200$ \\
\hline $271 \mathrm{~B}$ & 12,000 & 303 & $<200$ \\
\hline 272 & 6000 & 304 & $<200$ \\
\hline 273 & $<200$ & 305 & $<200$ \\
\hline 274 & $<200$ & 306 & $<200$ \\
\hline 275 & $<200$ & 307 & $<200$ \\
\hline 276 & $<200$ & 308 & $<200$ \\
\hline 277 & $<200$ & 309 & $<200$ \\
\hline 278 & $<200$ & 310 & $<200$ \\
\hline 279 & $<200$ & 311 & $<200$ \\
\hline 280 & $<200$ & 312 & $<200$ \\
\hline 281 & $<200$ & 313 & 600 \\
\hline 282 & $<200$ & 374 & 7000 \\
\hline 283 & $<200$ & 315 & 7000 \\
\hline 284 & 600 & 316 & 4000 \\
\hline 285 & $<200$ & 317 & 10,000 \\
\hline 286 & $<200$ & 318 & 800 \\
\hline 287 & 750 & 319 & 2500 \\
\hline 288 & $<200$ & 320 & 5000 \\
\hline 289 & $<200$ & 321 & $<200$ \\
\hline 290 & 2500 & 322 & $<200$ \\
\hline
\end{tabular}




\begin{tabular}{|c|c|c|c|}
\hline $\begin{array}{l}\text { Plant } \\
\text { Numbers }\end{array}$ & $\begin{array}{c}\text { Counts per } \\
\text { Minute }\end{array}$ & $\begin{array}{l}\text { Plants } \\
\text { Numbers }\end{array}$ & $\begin{array}{c}\text { Counts per } \\
\text { Minute }\end{array}$ \\
\hline 323 & $<200$ & 356 & $<200$ \\
\hline 324 & 7500 & 357 & $<200$ \\
\hline 325 & $<200$ & 358 & $<200$ \\
\hline 326 & $<200$ & 359 & $<200$ \\
\hline 327 & $<200$ & 360 & $<200$ \\
\hline 328 & $<200$ & 361 & 750 \\
\hline 329 & $<200$ & 362 & 2500 \\
\hline 330 & $<200$ & 363 & 3000 \\
\hline 331 & $<200$ & 364 & $<200$ \\
\hline 332 & $<200$ & 365 & 1000 \\
\hline 333 & $<200$ & 366 & 8000 \\
\hline 334 & $<200$ & 367 & $<200$ \\
\hline 335 & $<200$ & 368 & $<200$ \\
\hline 336 & $<200$ & 369 & $<200$ \\
\hline 337 & $<200$ & 370 & $<200$ \\
\hline 338 & 8000 & 371 & $<200$ \\
\hline 339 & 8000 & 372 & $<200$ \\
\hline 340 & 400 & 373 & $<200$ \\
\hline 341 & 2000 & 374 & $<200$ \\
\hline 342 & 750 & 375 & $<200$ \\
\hline 343 & $<200$ & 376 & 800 \\
\hline 344 & $<200$ & 377 & $<200$ \\
\hline 345 & 5000 & 378 & $<200$ \\
\hline 346 & 4500 & 379 & $<200$ \\
\hline 347 & $<200$ & 380 & 4000 \\
\hline 348 & $<200$ & 381 & $<200$ \\
\hline 349 & $<200$ & 382 & $<200$ \\
\hline 350 & $<200$ & 383 & 500 \\
\hline 351 & $<200$ & 384 & $<200$ \\
\hline 352 & $<200$ & 385 & $<200$ \\
\hline 353 & $<200$ & 386 & $<200$ \\
\hline 354 & $<200$ & 387 & $<200$ \\
\hline 355 & $<200$ & 388 & $<200$ \\
\hline
\end{tabular}




\begin{tabular}{|c|c|c|c|}
\hline $\begin{array}{l}\text { Plants } \\
\text { Numbers }\end{array}$ & $\begin{array}{c}\text { Counts per } \\
\text { Minute }\end{array}$ & $\begin{array}{l}\text { Plants } \\
\text { Numbers }\end{array}$ & $\begin{array}{c}\text { Counts per } \\
\text { Minute }\end{array}$ \\
\hline 389 & $<200$ & 421 & 4000 \\
\hline 390 & 550 & 422 & $<200$ \\
\hline 391 & 800 & 423 & $<200$ \\
\hline 392 & $<200$ & 424 & $<200$ \\
\hline 393 & $<200$ & 425 & 1000 \\
\hline 394 & $<200$ & 426 & $<200$ \\
\hline 395 & 5500 & 427 & 2500 \\
\hline 396 & $<200$ & 428 & $<200$ \\
\hline 397 & $<200$ & 429 & $<200$ \\
\hline 398 & $<200$ & 430 & $<200$ \\
\hline 399 & $<200$ & 431 & 3500 \\
\hline 400 & $<200$ & 432 & 800 \\
\hline 401 & $<200$ & 433 & 10,000 \\
\hline 402 & $<200$ & 434 & 5000 \\
\hline 403 & $<200$ & 435 & 10,000 \\
\hline 404 & $<200$ & 436 & 8000 \\
\hline 405 & $<200$ & 437 & 8000 \\
\hline 406 & $<200$ & 438 & 10,000 \\
\hline 407 & $<200$ & 439 & $<200$ \\
\hline 408 & $<200$ & 440 & 1000 \\
\hline 409 & $<200$ & 441 & $<200$ \\
\hline 410 & 5000 & 442 & 7000 \\
\hline 411 & $<200$ & 443 & $<200$ \\
\hline 412 & 700 & 444 & 4500 \\
\hline 413 & $<200$ & 445 & 7000 \\
\hline 414 & $<200$ & 446 & $<200$ \\
\hline 415 & $<200$ & 447 & $<200$ \\
\hline 416 & $<200$ & 448 & $<200$ \\
\hline 417 & 4500 & 449 & $<200$ \\
\hline 418 & 6000 & 450 & $<200$ \\
\hline 419 & 1000 & 451 & $<200$ \\
\hline 420 & $<200$ & 452 & $<200$ \\
\hline
\end{tabular}




\begin{tabular}{|c|c|c|c|}
\hline $\begin{array}{l}\text { Plant } \\
\text { Numbers }\end{array}$ & $\begin{array}{c}\text { Counts per } \\
\text { Minute }\end{array}$ & $\begin{array}{l}\text { Plant } \\
\text { Numbers }\end{array}$ & $\begin{array}{c}\text { Counts per } \\
\text { Minute }\end{array}$ \\
\hline 453 & 2000 & 486 & $<200$ \\
\hline 454 & 3000 & 487 & $<200$ \\
\hline 455 & 800 & 488 & $<200$ \\
\hline 456 & $<200$ & 489 & $<200$ \\
\hline 457 & 6000 & 490 & $<200$ \\
\hline 458 & $<200$ & 491 & $<200$ \\
\hline 459 & $<200$ & 492 & $<200$ \\
\hline 460 & 1000 & 493 & $<200$ \\
\hline 461 & $<200$ & 494 & $<200$ \\
\hline 462 & $<200$ & 495 & $<200$ \\
\hline 463 & $<200$ & 496 & $<200$ \\
\hline 464 & $<200$ & 497 & $<200$ \\
\hline 465 & $<200$ & 498 & $<200$ \\
\hline 466 & $<200$ & 499 & $<200$ \\
\hline 467 & $<200$ & 500 & $<200$ \\
\hline 468 & $<200$ & 501 & $<200$ \\
\hline 469 & $<200$ & 502 & $<200$ \\
\hline 470 & 7000 & 503 & 1500 \\
\hline 471 & 2000 & 504 & 4500 \\
\hline 472 & $<200$ & 505 & 6000 \\
\hline 473 & $<200$ & 506 & 6000 \\
\hline 474 & 1000 & 507 & 8000 \\
\hline 475 & $<200$ & 508 & $<200$ \\
\hline 476 & $<200$ & 509 & 4000 \\
\hline 477 & $<2000$ & 510 & $<200$ \\
\hline 478 & $<200$ & 511 & $<200$ \\
\hline 479 & $<200$ & 512 & $<200$ \\
\hline 480 & $<200$ & 513 & 1000 \\
\hline 481 & $<200$ & 514 & 3000 \\
\hline 482 & $<200$ & 515 & 6000 \\
\hline 483 & $<200$ & 516 & $<200$ \\
\hline 484 & 1000 & 517 & $<200$ \\
\hline 485 & $<200$ & & \\
\hline
\end{tabular}




\section{APPENDIX III}

Radionuclides in leaves of plants growing along the central transect of Section I I of the 216-A-24 Crib, strontium was determined by chemical precipitation followed by counting on a low beta proportional counter. Other radionuclides were determined by gamma energy analysis of scans obtained with a NaI crystal. Blanks are shown where standard errors were greater than the calculated value.

\begin{tabular}{|c|c|c|c|c|c|c|}
\hline $\begin{array}{l}\text { Plant } \\
\text { Number }\end{array}$ & $\begin{array}{r}90 \mathrm{Sr} \\
\mathrm{nC} i / \mathrm{gDW} \\
\end{array}$ & $\begin{array}{r}137 \mathrm{Cs} \\
\mathrm{nCi} / \mathrm{gDW} \\
\end{array}$ & $\begin{array}{c}144 \mathrm{Ce} \\
\mathrm{nCi} / \mathrm{gDW} \\
\end{array}$ & $\begin{array}{c}106 \mathrm{Ru} \\
\mathrm{nCi} / \mathrm{gDW} \\
\end{array}$ & $\begin{array}{c}95 \mathrm{Zr} \\
\mathrm{nCi} / \mathrm{gDW} \\
\end{array}$ & $\begin{array}{c}54 \mathrm{Mn} \\
\mathrm{nCi} / \mathrm{gDW} \\
\end{array}$ \\
\hline $\begin{array}{r}94 \\
95 \\
102 \\
106 \\
118 \\
119 \\
120 \\
124 \\
142 \\
143 \\
147 \\
148 \\
149 \\
150 \\
192 \\
194 \\
195 \\
196 \\
198 \\
221 \\
222 \\
224 \\
268 \\
269 \\
270 \\
295 \\
314 \\
316 \\
341 \\
342 \\
343 \\
344\end{array}$ & $\begin{array}{l}0.0035 \\
0.0666 \\
0.0158 \\
0.385 \\
0.0609 \\
0.0206 \\
0.0795 \\
0.285 \\
0.00259 \\
0.00740 \\
0.0128 \\
1.790 \\
0.756 \\
0.035 \\
0.115 \\
0.140 \\
0.725 \\
0.00413 \\
0.801 \\
1.790 \\
0.0664 \\
0.0476 \\
0.832 \\
0.418 \\
0.976 \\
0.0276 \\
0.505 \\
0.0002 \\
0.0264 \\
0.085 \\
0.0295 \\
0.00186\end{array}$ & $\begin{array}{c}-- \\
27.2 \\
2.75 \\
24.8 \\
11.6 \\
18.1 \\
69.7 \\
104 \\
0.316 \\
62.3 \\
72.6 \\
891 \\
255 \\
188 \\
73.7 \\
82.7 \\
699 \\
0.18 \\
591 \\
517 \\
266 \\
22.5 \\
184 \\
93.6 \\
231 \\
0.79 \\
68.0 \\
30.7 \\
51.3 \\
14.1 \\
-- \\
0.036 \\
\end{array}$ & $\begin{array}{c}-- \\
3.84 \\
0.40 \\
4.11 \\
1.32 \\
2.59 \\
11.6 \\
20.5 \\
-- \\
9.7 \\
12.7 \\
170 \\
54 \\
37 \\
12.2 \\
14.0 \\
162 \\
-- \\
90.1 \\
109 \\
50.5 \\
3.59 \\
0.36 \\
15.1 \\
43.0 \\
-- \\
11.7 \\
4.7 \\
7.89 \\
1.89 \\
-- \\
-- \\
\end{array}$ & $\begin{array}{c}-- \\
-- \\
-- \\
2.12 \\
-- \\
1.36 \\
-- \\
8.0 \\
-- \\
5.1 \\
6.40 \\
54.1 \\
16.8 \\
8.6 \\
-- \\
-- \\
51.0 \\
-- \\
-- \\
34.8 \\
19.3 \\
-- \\
-- \\
3.04 \\
13.8 \\
-- \\
-- \\
-- \\
-- \\
-- \\
-- \\
-- \\
\end{array}$ & $\begin{array}{l}-- \\
0.2 \\
0.04 \\
0.2 \\
0.1 \\
0.1 \\
0.6 \\
0.8 \\
-- \\
0.3 \\
0.46 \\
9.6 \\
2.17 \\
1.54 \\
0.99 \\
0.91 \\
7.36 \\
-- \\
7.32 \\
4.83 \\
2.27 \\
0.29 \\
1.5 \\
0.93 \\
1.94 \\
-- \\
0.96 \\
-- \\
0.55 \\
0.11 \\
-- \\
-- \\
\end{array}$ & $\begin{array}{l}-- \\
0.1 \\
-- \\
0.08 \\
-- \\
0.06 \\
0.2 \\
0.47 \\
-- \\
0.25 \\
0.3 \\
4.1 \\
0.97 \\
0.71 \\
0.21 \\
0.31 \\
2.94 \\
-- \\
3.1 \\
2.50 \\
1.17 \\
-- \\
0.78 \\
0.33 \\
0.98 \\
-- \\
-- \\
-- \\
-- \\
0.05 \\
-- \\
-- \\
\end{array}$ \\
\hline Average & 0.316 & 145 & 21.9 & 7.0 & 1.44 & 0.61 \\
\hline $\begin{array}{c}\text { Standaro } \\
\text { Error }\end{array}$ & 0.086 & 39.4 & 6.5 & 2.5 & 0.43 & 0.19 \\
\hline
\end{tabular}




\section{DISTRIBUTION LIST}

No. of

Copies

$\underline{\text { OFFSITE }}$

A. A. Churm

DOE Chicago Patent Attorney

9800 South Cass Avenue

Argonne, IL 60439

(27) DOE Technical Information Center

Department of Energy

R. C. Clusen

Assistant Secretary for

Environment

Washington, DC 20545

P. B. Dunaway

Nevada Operations Office

P.0. Box 14100

Las Vegas, NV 89114

J. L. Liverman

Deputy Assistant Secretary

for Environment

Washington, DC 20545

0. D. Markham

Radiological and Environmental Sciences Laboratory

Idaho Operations office

550 Second Street

Idaho Fal1s, ID 83401

S. Meyers

Office of Nuclear Waste

Management

Washington, DC 20545
No. of

Copies

OFFSITE

(8) DOE Office of Health and

Environmental Research

Washington, DC 20545
N. F. Barr
W. W. Burr
C. E. Carter
R. C. Dah Iman
R. E. Frank 1 in
W. S. Osburn
J. Swinebroad
R. L. Watters

Others

S. I. Auerbach

Oak Ridge National

Laboratory

P.0. Box $X$

Oak Ridge, TN 37830

I. L. Brisbin, Jr.

Savannah River Ecology Laboratory

Aiken, SC 29801

H. C. Burkholder

Office of Nuclear Waste

Isolation

Battelle Memorial Institute

505 King Avenue

Columbus, $\mathrm{OH} 43201$

J. J. Davis

Office of Nuclear Regulatory Research

U.S. Nuclear Regulatory

Commission

Washington, D.C. 20545 
OFFSITE

T. E. Hakonson

Los Alamos Scientific Laboratory

P.0. Box 1663

Los Alamos, NM 86544

M. Smith, Director

Savannah River Ecology Laboratory

Drawer E

Aiken, SC 29801

F. W. Whicker

Radiology and Radiation

Biology Department

Colorado State University

Fort Collins, CO 80521

\section{ONSITE}

United Nuclear Inc.

T. E. Dabrowski

Hanford Engineering Development Laboratory

G. D. Carpenter

(10) DOE - Rich land Operations

J. C. Cummings

O. J. Elgert/J. L. Roades

R. E. Gerton

B. R. Goranson

H. E. Ransom/F. Austin

M. W. Shupe

F. R. Standerfer/P. G. Harris

M. W. Tiernan/D. R. Elle

M. G. White/P. F. Dunigan

M. J. Zamorsk i
ONSITE

(30) Rockwe 11 Hanford Operations

H. Babad

D. J. Brown

L. E. Bruns

J. L. Deichman

R. D. Fox

R. J. Gimera

M. K. Harmon

W. F. Heine

R. E. Isaacson

J. E. Kinser

C. W. Manry

D. A. Marsh

H. E. McGuire

L. P. McRae

R. M. Mitchel1 (10)

G. C. Owens

D. Paine

J. V. Panesko

J. H. Roecker

J. A. Swenson

D. D. Wodr ich

(34) Pacific Northwest Laboratory

W. J. Bair

L. L. Cadwe 11 (15)

B. W. Compton

J. J. Fuquay

D. E. Olesen

R. H. Rickard

L. E. Rogers

R. G. Schreckhise

W. L. Temp leton

B. E. Vaughan

Technical Information

Publishing Coordination

NE 